\title{
45. MULTICHANNEL SEISMIC REFLECTION SURVEY OF THE SOUTHEASTERN ANGOLA BASIN1
}

\author{
Lee A. Musgrove ${ }^{2}$ and James A. Austin, Jr., Institute for Geophysics, \\ The University of Texas at Austin, Austin, Texas
}

\begin{abstract}
The geologic evolution of the southeastern Angola Basin and contiguous Walvis Ridge in the vicinity of Site 530 is examined here using multichannel seismic reflection data collected by the University of Texas and Bundesanstalt für Geowissenschaften und Rohstoffe (BGR). Seismic stratigraphic and facies analyses are used to discuss: (1) configuration of oceanic basement, (2) structure of the eastern Walvis Ridge, and (3) stratigraphic history of the southern basin fill.

Angola Basin acoustic basement, interpreted in this chapter as the boundary between oceanic crust and overlying sediments, is characterized by north-northwest-striking ridges and troughs which parallel the local paleo-midocean ridge axis. This basement morphology may perhaps be inherited from the original formation of oceanic crust. The Walvis Ridge/Angola Basin basement boundary appears to be a single fault plane dipping $9-10^{\circ} \mathrm{NNW}$. Subsidence of acoustic basement increases northward away from the base of the ridge.

The seismic stratigraphy of the southeastern Angola Basin can be divided into four major sequences. Unit 1 illustrates early deposition of turbidite sediments controlled by basement topography. Unit 2 consists of three or more cycles of very high amplitude, subparallel reflectors and minor channeling, indicative of a deep-sea fan sequence composed of acoustically contrasting lithologies. The Unit $2 / 3$ boundary is a major seismic discontinuity that is recognized throughout the entire Angola Basin and that has been previously correlated with reflector "AII" in the Cape Basin south of the Walvis Ridge. Unit 3 is an almost transparent sequence that onlaps the basinward-sloping top of Unit 2. Its reflection characteristics suggest that Unit 3 was deposited by low-energy turbidity currents with only a minor pelagic component. The top of Unit 3 is another major unconformity associated with a rapid increase in reflection amplitude. Unit 4 is characterized by overlapping lenticular mounds and hummocky reflections indicating deposition by highenergy gravity flows. Two minor unconformities are apparent within the unit.

Throughout the deposition of Units 1,2, and 4, there is evidence of considerable deep-water erosion and sediment reworking, particularly along the base of the Walvis Ridge. Unit 3 appears to represent the most tranquil period in the history of the Angola Basin. Based on seismic reflection configurations, the sediment source for Units 1-3 was the African continental margin. The Walvis Ridge becomes the dominant source only with the onset of Unit 4 deposition.
\end{abstract}

\section{INTRODUCTION}

The broad objective of this investigation is to use high-quality multichannel seismic reflection data available in the vicinity of Site 530 to describe the structural and stratigraphic history of the southeastern Angola Ba$\sin$. More specifically, the interpretation focuses on the structure of acoustic basement, the facies characteristics of the overlying sedimentary units, and the nature of intervening seismic unconformities. The data density is adequate for mapping of both sequence boundaries and thicknesses. With these maps, provenance can be generally determined, thereby putting the results from Site 530 into a regional perspective.

\section{Site Survey Data Base}

To prepare for Leg 75 drilling, the University of Texas Institute for Geophysics' (UTIG) $R / V$ Fred $H$. Moore conducted detailed multichannel seismic surveys in the Angola Basin in May 1979. The site surveys for Hole 530 resulted in a $360 \mathrm{~km}$ grid of 6-trace, 18-fold common-depth-point (CDP) air-gun profiles (AM-27 to

\footnotetext{
${ }^{1}$ Hay, W. W., Sibuet, J.-C., et al., Init. Repts. DSDP, 75: Washington (U.S. Govt. Printing Office).

2 Present address: AMOCO Production Company-U.S.A., P.O. Box 3092, Houston, TX 77253 .
}

-37) covering more than $3,000 \mathrm{~km}^{2}$ (Fig. 1). In addition, a 650 -km long, 24-trace, 12-fold air-gun profile (AM-26) was collected enroute to the site survey area from the south-central part of the Angola Basin (Fig. 2). For both data sets, a $2.6 \mathrm{~km}$ receiving array (group intervals of $400 \mathrm{~m}$ and $100 \mathrm{~m}$, respectively) was employed. The sound source consisted of three 1500 in. ${ }^{3}$ air guns fired simultaneously at $400-500$ p.s.i. Multiplexed data were recorded every 4 milliseconds on 1 in., 21-track magnetic tapes using a Texas Instruments DFS IV. (See Musgrove, 1982, for a complete discussion of acquisition parameters.)

Other seismic reflection data used in the course of this investigation included 48-trace, 24 -fold profile BGR 78-41 and single-channel records from the $D / V$ Glomar Challenger (Legs 40 and 75) (Fig. 1). A sonobuoy collected during the 1971 Walda cruise of the $R / V$ Jean Charcot provided additional vertical velocity information (Figs. 1 and 26).

\section{Seismic Processing}

All CDP analysis was carried out at The University of Texas Galveston Marine Geophysics Laboratory on a Petty Ray TEMPUS seismic processing system. The standard processing sequence included: demultiplexing, editing (noisy traces), trace gathering or sorting, semblance velocity analysis, normal moveout corrections, stacking, bandpass filtering $(5-50 \mathrm{~Hz}$ for AM-27 to $-37,8-64$ 


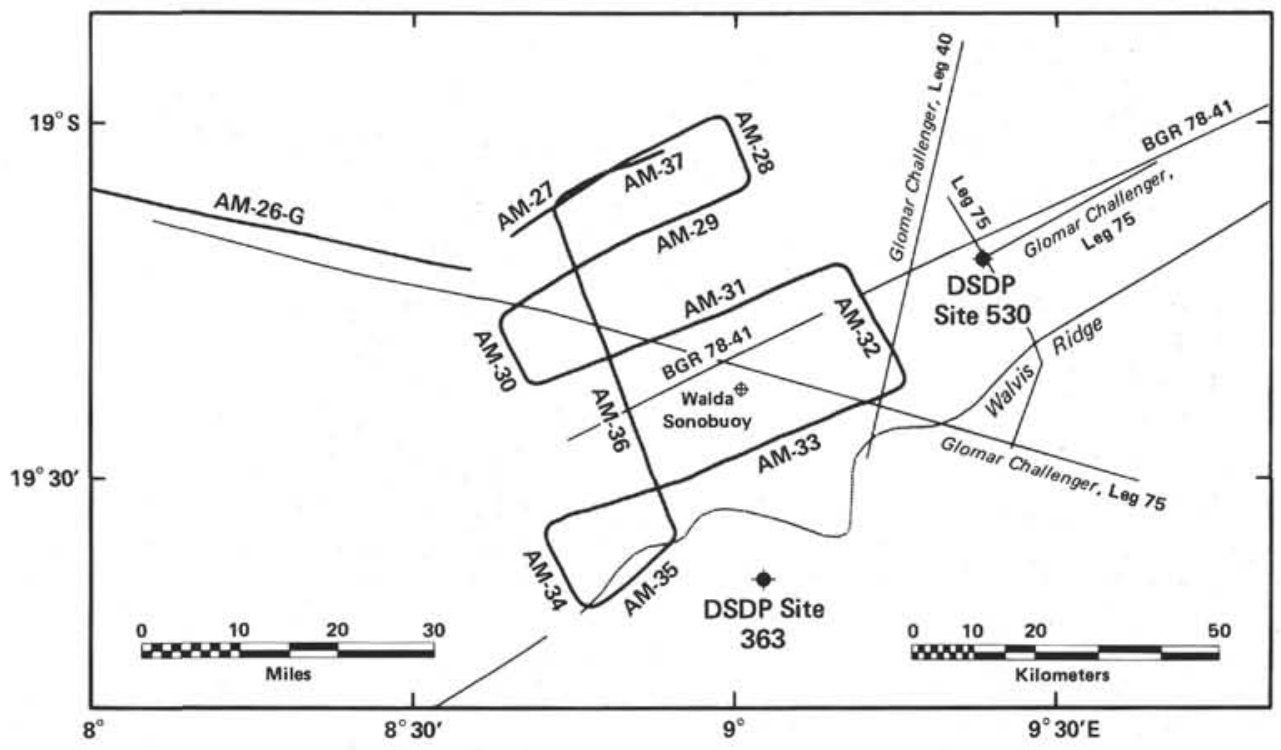

Figure 1. Locations of single and multichannel seismic reflection profiles in the vicinity of Site 530. Heavy lines are the UTIG multichannel site survey lines AM-27 to -37, thin lines are the D/V Glomar Challenger profiler records (Legs 40 and 75 ) and the BGR 78-41 multichannel seismic line. Also plotted are the locations of DSDP Sites 530 (Leg 75) and 363 (Leg 40), and a Walda sonobuoy launching point. (Note: Some proprietary multichannel information used in this investigation has been omitted.)

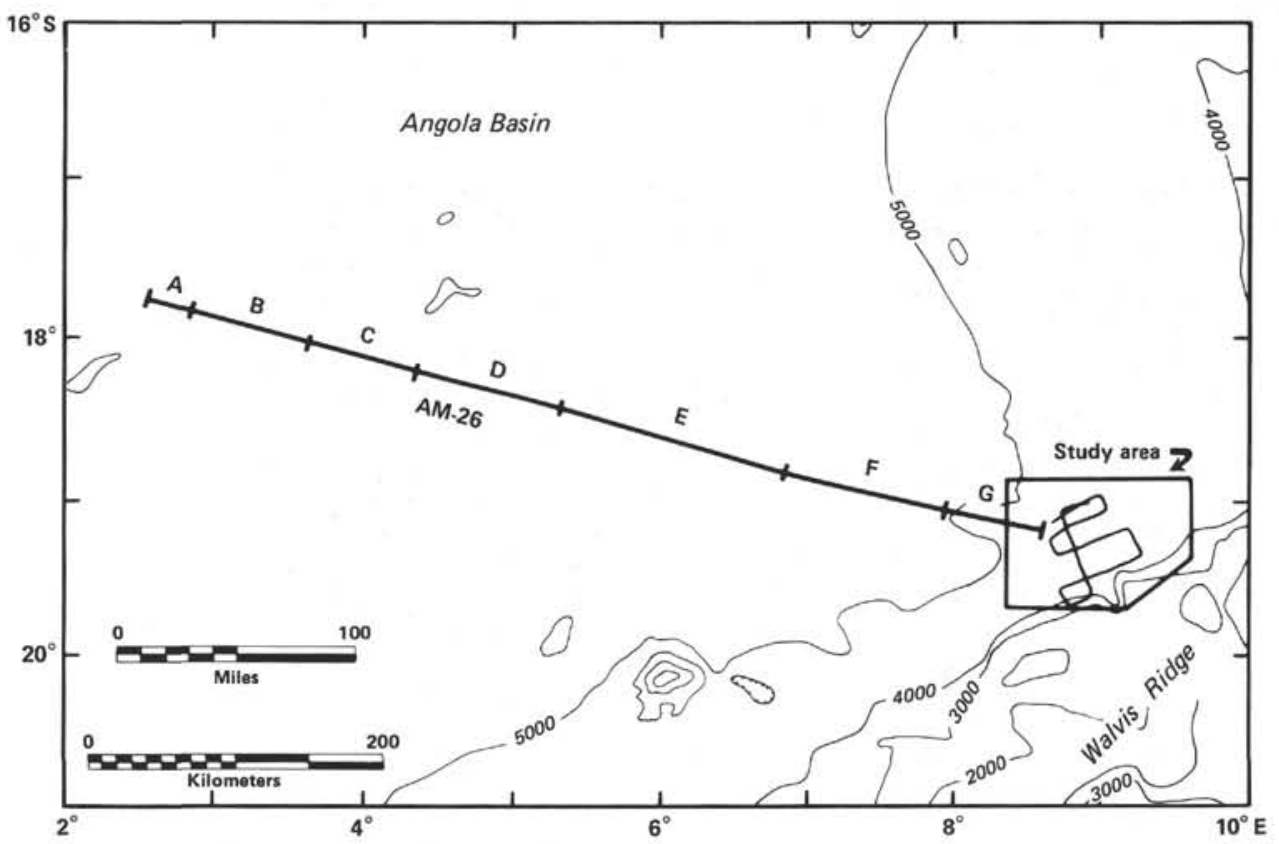

Figure 2. Location of UTIG regional multichannel line AM-26.

$\mathrm{Hz}$ for AM-26), automatic gain control (AGC) scaling, and cosmetic muting (water column noise). On lines AM-27 to -37, spike deconvolution to remove effects of air-gun generated bubble-pulse oscillations from the outgoing wavelet was also applied (see Musgrove, 1982).

\section{SEISMIC REFLECTION CHARACTERISTICS}

\section{Method of Interpretation}

The techniques of seismic stratigraphic analysis (Vail et al., 1977) were used to identify acoustic basement and four major sequence boundaries in the southeastern An- gola Basin. These were traced on the UTIG profiles, then tied to the other reflection data in the Site 530 survey area. For each seismic stratigraphic unit, structure and isopach maps in two-way travel time were constructed, and three-dimensional facies characteristics were described. Then, possible depositional settings were described as part of a general summary of the geologic history of the basin.

\section{Acoustic Basement}

The acoustic basement surface in the Site 530 survey area is interpreted here as the boundary between oceanic 
crust and overlying sedimentary strata. This boundary is generally marked by a large contrast in acoustic impedance which produces a characteristic reflection pattern on the air gun-generated seismic profiles. In a sedimentary column, the effects of an oscillating air-gun bubble pulse are generally suppressed by interference with reflections from numerous, contrasting impedance interfaces. However, when the source wavelet strikes a strong impedance contrast (e.g., that between sediments and basaltic crust) that is not underlain by additional interfaces, a characteristic "ringing" reflection is the result. This effect is enhanced by AGC-scaling the CDPstacked data.

On near-trace gathers (Fig. 3), basement in this region appears either as a group of high-amplitude, lowfrequency diffractions, or as a series of relatively smooth, subparallel horizons. The diffractions have uniform shapes, suggesting that they are generated by a rough surface with a distinct grain. They are more common on east-west trending profiles, while the smoother, subparallel reflections dominate on north-south profiles (Fig. 3 ). All of this evidence suggests the presence of northsouth trending basement ridges and troughs in the southeastern Angola Basin. The diffractions would be produced by shooting across the trend of the ridges, while the subparallel reflections would be the result of isonification of the flanks and crests of adjacent ridges while shooting along their strike (Musgrove, 1982).

The maps of the acoustic basement surface (Figs. 4 and 5) show that it dips generally north-northwest from a high of $5.3 \mathrm{~km}$ near the base of the Walvis Ridge to a low of $6.3 \mathrm{~km}$ at the northern limit of the study area (conversion from two-way travel time to depth using
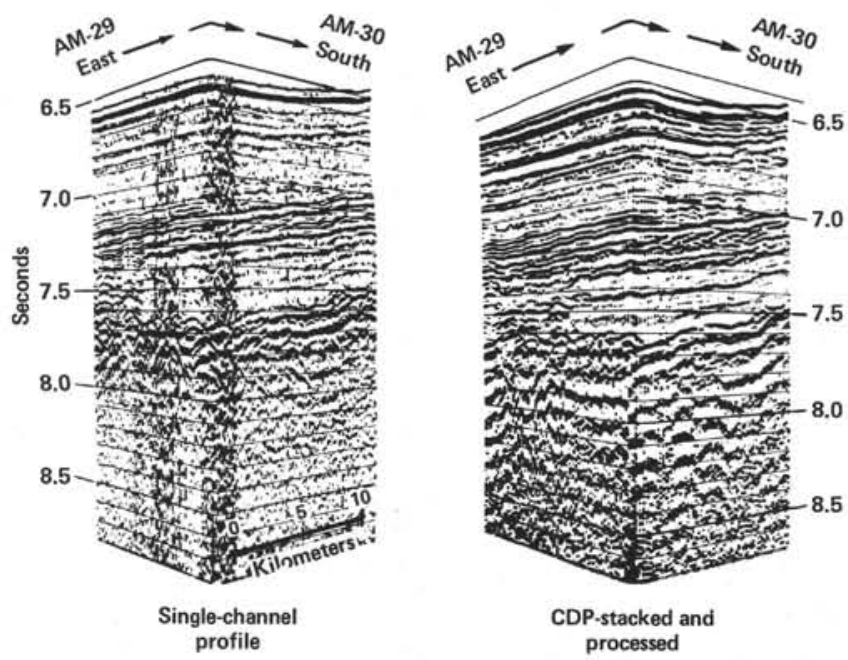

Figure 3. An isometric view looking towards the southwest of the intersection of lines AM-29 and AM-30. Both single-channel profiles (near-trace gathers) and CDP-stacked data are represented. Note the enhanced ringing of the basement reflection (7.5-7.7 s) on the stacked and AGC-scaled data. The characteristics of the basement horizon also depend upon azimuth of the profile. On east-west trending AM-29, basement appears as a series of closely-spaced hyperbolic arcs, while on north-south trending AM-30, the same surface generates a series of semi-continuous, subparallel reflections. stacking velocities, see Musgrove, 1982). As expected from the individual profiles, the top of acoustic basement is highly irregular, dominated by ridges and troughs roughly perpendicular to the strike of the Walvis Ridge escarpment (Fig. 4). Spacing between the ridge crests is 30 to $35 \mathrm{~km}$. Two broad, irregular ridges separated by a narrow trough occur at the base of the Walvis Ridge (Fig. 5). Their steep flanks suggest that they are faultbounded (Fig. 6). The ridges correspond to salients of the Walvis Ridge, while the trough lies at the mouth of a narrow canyon in the escarpment. A third, fault-bounded ridge is located about $10 \mathrm{~km}$ east of DSDP Site 530 (Fig. 5). It is separated from the two ridges to the west by a relatively broad trough that appears to parallel the strike of the Walvis Ridge. Neither the eastern ridge nor the intervening trough correspond to any distinct change in trend of the Walvis Ridge escarpment (Fig. 5).

A second-order lineation superimposed on the northnorthwest trending basement ridges produces a variation in elevation along their strike. The axis of the westernmost basement ridge undulates, reaching a low-point about $40 \mathrm{~km}$ north-northwest of the base of the Walvis Ridge escarpment (Fig. 5). Another trough is visible at the northernmost boundary of the study area along the axis of the central basement high. Such a phenomenon has already been described for the Galapagos spreading system (Allmendinger and Riis, 1979), and this suggests that most of the southeastern Angola Basin basement topography is inherited from the original formation of oceanic crust.

Superimposed on the large-scale structures are smaller isolated highs and lows (Fig. 4). Several highs about 4-5 km across are possible volcanic cones (Fig. 5), although they could also represent structural ridges too small to be resolved completely by the available seismic coverage. In addition, smaller-scale undulations of 1-5 $\mathrm{km}$ wavelengths occur. These are more apparent on the north-south lines, implying that they are an outgrowth of the general north-northwest structural trend of the basement surface.

\section{STRATIGRAPHIC UNITS}

\section{Unit 1}

The depositional sequence overlying acoustic basement is characterized by a series of low- to moderateamplitude reflectors that form a variety of reflection configurations. The base of Unit 1 downlaps, onlaps, and terminates abruptly against acoustic basement. Near the base of the Walvis Ridge, however, low- to high-amplitude reflectors either fill basement lows (Fig. 7, depth points [DPT] 30-50) or downlap basement in a southward prograding pattern (Fig. 8).

Generally, the lower half of Unit 1 consists of lowamplitude, discontinuous to slightly hummocky or chaotic reflectors that onlap basement highs. The hummocky, chaotic reflectors tend to be more common on east-west profiles (Fig. 9), while on north-south profiles Unit 1 reflectors more often slope basinward as a series of discontinuous, subparallel, downlapping reflections (Fig. 7). There is a slight increase in reflector 


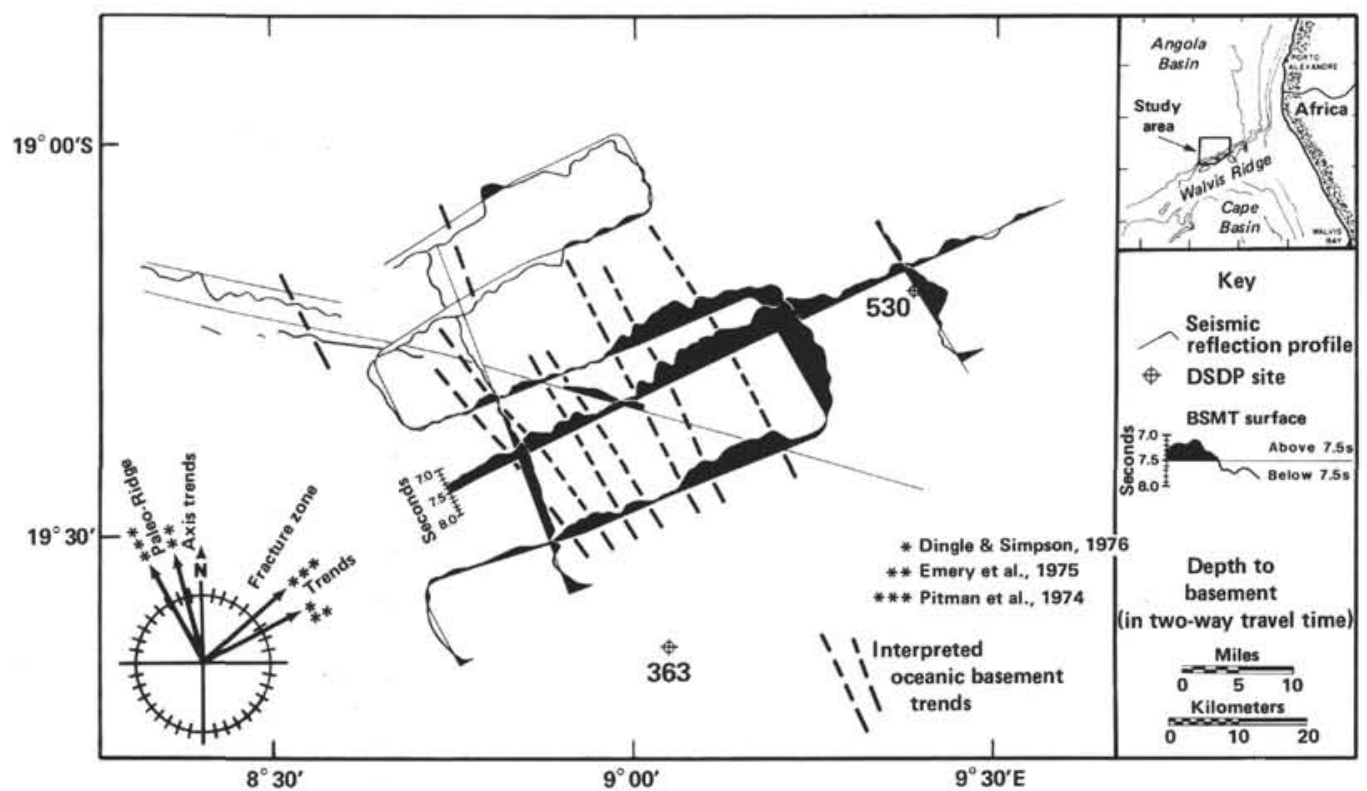

Figure 4. Fence diagram of the interpreted oceanic basement surface showing basement topography above and below $7.5 \mathrm{~s}$ (two-way travel time). Local paleo-mid-ocean ridge axis and fracture zone trends (from Pitman et al., 1974, Emery et al., 1975, and Dingle and Simpson, 1976) are plotted in reference to the present North Pole. Seismic lines have been identified to facilitate the comparison of the basement interpretation presented here with the actual seismic data.

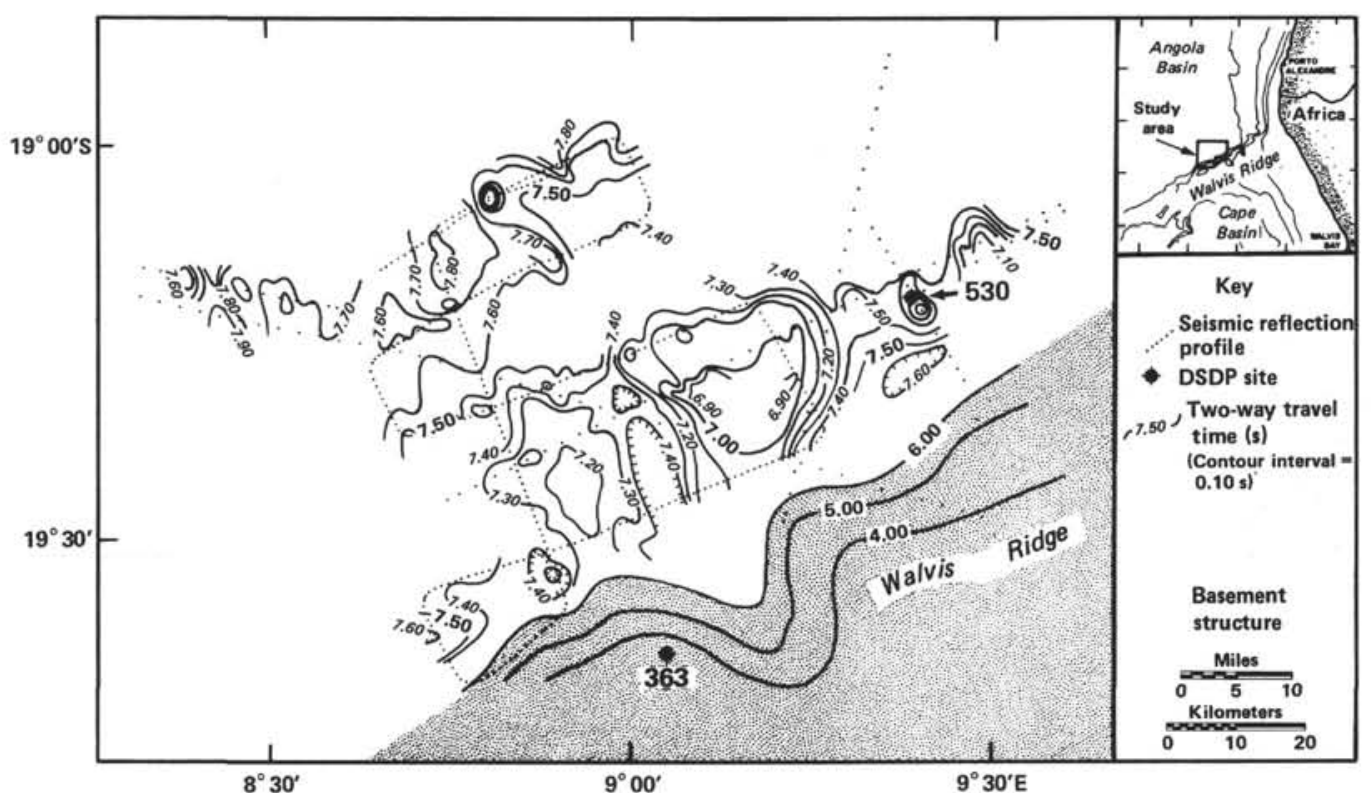

Figure 5. Interpretive structure map of acoustic basement surface (in two-way travel time). Bathymetry of the Walvis Ridge (stippled area; from Rabinowitz, pers. comm.) is shown converted to two-way travel time assuming water velocity $=1.5 \mathrm{~km} / \mathrm{s}$. The actual seismic control is shown in Figure 4.

continuity and amplitude both upward and to the north. In the basin away from the Walvis Ridge, reflectors slope to the west on east-west profiles and more gently to the north on north-south lines, suggesting a general dip to the west-northwest. However, divergent reflections slope off local highs into basement lows in all directions (see Fig. 7, DPT 120-140 and Fig. 8, field record numbers [FLD] 1350-1400).

Unit 1 is divided by a moderate-amplitude, semicontinuous reflector that appears to correlate with the erosional base of several channels observed on both east-west and north-south profiles (Figs. 10 and 7, DPT 190-220). The channels exhibit both complex-fill and onlap-fill reflection patterns. Away from these channels, the reflections overlying the minor unconformity are generally subparallel and discontinuous, although they are hummocky to chaotic in places. The top of Unit 1 is truncated by an undulating unconformity (Fig. 7-10).

The isopach map shows Unit 1 to be a highly irregular sequence whose thickness is controlled by the topog- 


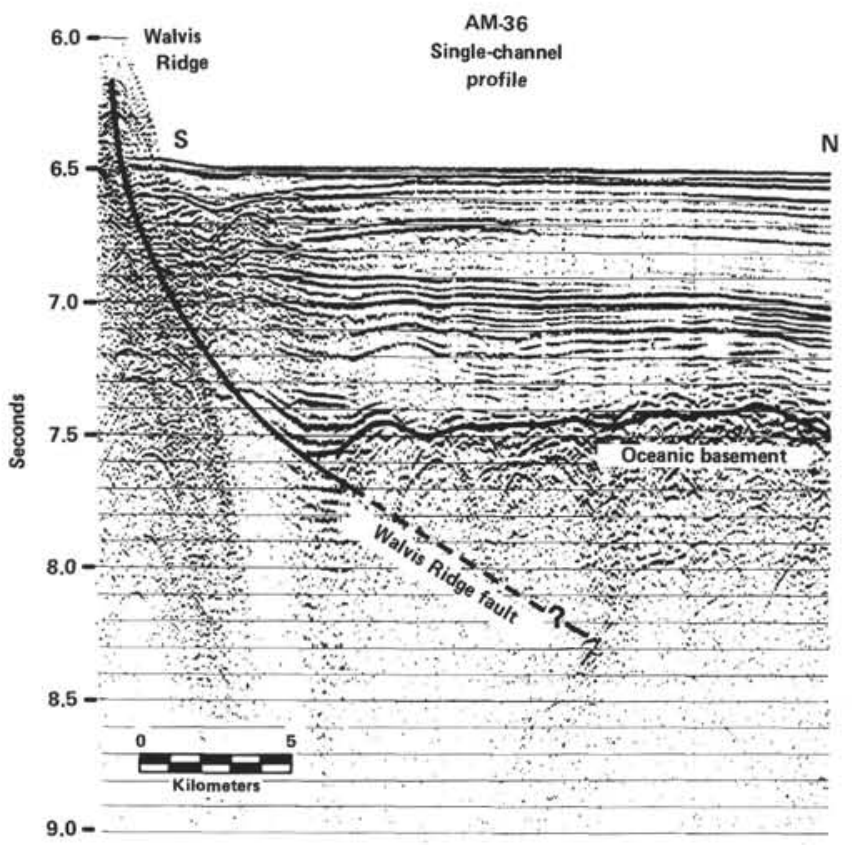

Figure 6. Location of the fault plane believed to form the northern face of the Walvis Ridge escarpment. The fault position is estimated from the termination of sediment reflectors against the ridge. The fault appears to be a curved, concave-upward surface in traveltime, but is actually planar with only $9^{\circ}-10^{\circ}$ slope when converted to depth (using interval velocities, Musgrove, 1982). Also note differential compaction of basin sediments over basement topography.

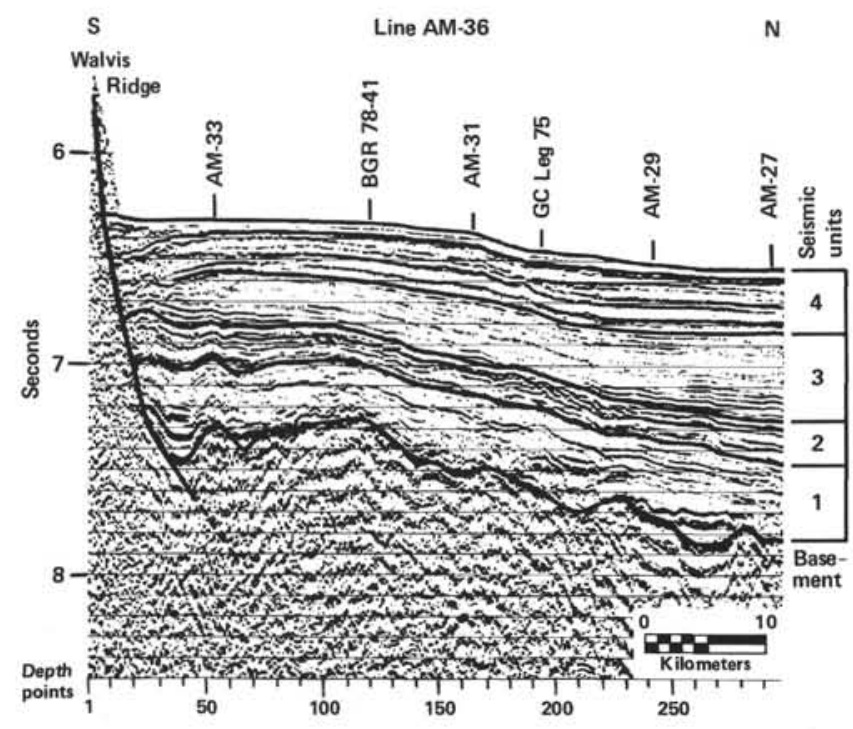

Figure 7. UTIG line AM-36 showing the four seismic sequences which are traced throughout the site survey area. Unit 1 displays a variety of reflection patterns. Several basement lows are filled with onlapping, high-amplitude reflections. Divergent reflectors slope to the north off local highs. The unit is divided by a minor unconformity (7.2 s at DPT 150) that may correlate with the base of a channeling facies (DPT 190-220). Unit 2, characterized by high-amplitude, subparallel reflectors, exhibits an unusual sigmoidal clinoform facies about $30 \mathrm{~km}$ north of the Walvis Ridge. At the northern end of the line, Unit 2 reflectors appear to onlap to the south. Unit 3 is divided by an unconformity (6.8 $s$ at DPT 140 ) above which divergent reflectors slope basinward. Unit 4 reflections become more continuous away from the ridge but also exhibit an onlapping mounded facies. raphy of underlying basement (Figs. 11 and 5). Sediment accumulations are larger in lows than over highs. Assuming an interval velocity of $2.66 \mathrm{~km} / \mathrm{s}$ (from stacking velocities), the average thickness of Unit 1 is $400 \pm$ $130 \mathrm{~m}$. However, wide variation occurs. For example, in the trough at the base of the Walvis Ridge near the eastern boundary of the study area, over $1,060 \mathrm{~m}(>0.8 \mathrm{~s}$ two-way travel time [t-wtt]) of Unit 1 sediments were deposited. Only $15 \mathrm{~km}$ northwest of this maximum, the sequence thins over a basement high to less than $130 \mathrm{~m}$ $(<0.1 \mathrm{~s} \mathrm{t}-\mathrm{wtt})$. To the southwest, an $800-\mathrm{m}$ thick $(>0.6 \mathrm{~s}$ $\mathrm{t}$-wtt) depocenter thins rapidly to the south.

The top of Unit 1 reflects both incomplete filling of basement lows and subsequent compaction by overlying sedimentary units (Fig. 12). This surface exhibits as much as $0.3 \mathrm{~s} \mathrm{(t-wtt)}$ of relief and resembles a smoothed version of the top of acoustic basement (Fig. 5). The two broad mounds resembling submarine fans at the base of the Walvis Ridge (Fig. 12) are actually separate basement highs only thinly covered by sediments. Clearly, Unit 1 deposition was largely controlled by basement topography.

Unit 2. From the central Angola Basin to the base of the African continental slope, Unit 2 is characterized by a series of uniformly continuous, high-amplitude, even to wavy parallel reflections (Fig. 13). At the southern boundary of the basin, Unit 2 covers the uneven top of Unit 1 in several reflection configurations. On northsouth profiles, the majority of reflectors downlap to the north, towards the basin, but there is also some onlap from the south (Fig. 7). On east-west profiles near the Walvis Ridge, Unit 2 reflectors usually downlap gently to the west or onlap topographic highs. However, right at the base of the Walvis Ridge, reflectors appear to downlap, onlap, and prograde to the south, towards the ridge (Fig. 7, DPT 60-110, and Fig. 8). Away from the ridge, reflections become concordant, draping pre-existing topography (Fig. 13). On all profiles, onlapping and downlapping channel deposits of Unit 2 fill in lows in the top of Unit 1 (Fig. 7, DPT 55-85, and Fig. 8).

Away from the Walvis Ridge, Unit 2 reflectors slope northward as a subparallel, semi-continuous series except where interrupted by a prograding clinoform facies observed on parallel north-south lines AM-30 (Fig. 14) and AM-36 (Fig. 7, DPT 170-220). The clinoforms prograde for about $15 \mathrm{~km}$ into the Angola Basin on gentle slopes from a line $30 \mathrm{~km}$ north of the ridge across a front at least $20 \mathrm{~km}$ wide. However, on seismic lines parallel to the ridge, corresponding horizons are discontinuous to hummocky, and are usually horizontal or slope to the west (Figs. 9 and 14).

Several trends are observed in Unit 2. First, there is an increase in seismic reflection continuity basinward as acoustic horizons become more parallel and evenly spaced. Second, reflection continuity increases upward in Unit 2 because parallel reflectors in the upper part of the unit tend to drape underlying topography.

Unit 2 maintains a relatively constant thickness of $240 \pm 60 \mathrm{~m}$ throughout the southeastern Angola Basin (assuming a $2.37 \mathrm{~km} / \mathrm{s}$ interval velocity, Fig. 15). The unit generally appears to thicken slightly to the north 


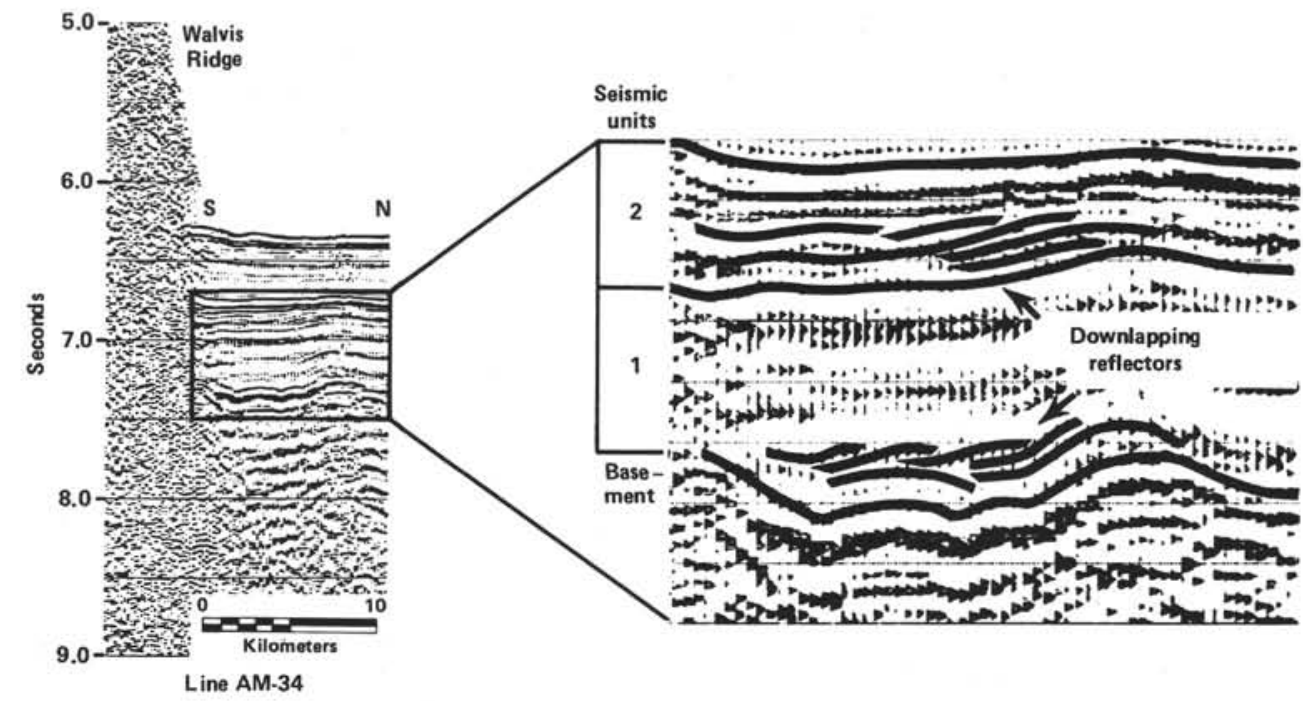

Figure 8. Line AM-34 showing downlapping reflectors that prograde toward the base of the Walvis Ridge in Units 1 and 2 . This facies may have been caused by localized channeling processes.

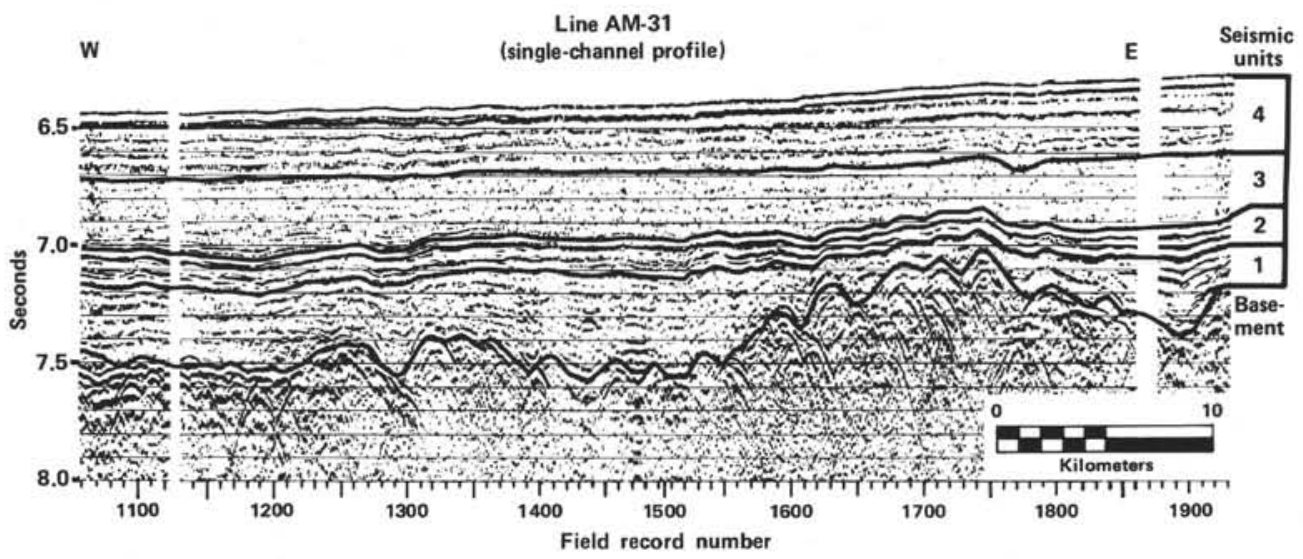

Figure 9. Single-channel (near-trace gather) display of seismic line AM-31 showing the true amplitude relationships of the seismic units about $30 \mathrm{~km}$ north of the Walvis Ridge.

and thin to the south against the Walvis Ridge (Figs. 7 and 15 ). Where variation does occur, it is a combined result of sediment thinning and differential compaction over basement highs (Fig. 13). This produces as much as a $25-30 \%$ reduction in thickness. Local thickening also occurs where Unit 2 sediments fill in depressions left at the top of Unit 1. Several small basins at the southwestern end of the study area contain more than $295 \mathrm{~m}(>0.25 \mathrm{~s}$ $\mathrm{t}$-wtt) of Unit 2 sediments, while only $120 \mathrm{~m}(<0.10 \mathrm{~s}$ t-wtt) cover a south-central high (Figs. 15 and 12).

The top of Unit 2 is a seismic discontinuity that is recognized as a major horizon throughout the Angola Basin (horizon "AII"; Emery et al., 1975; Bolli, Ryan et al., 1978). The map of this surface (Fig. 16) shows that the topography left after Unit 1 deposition has been largely smoothed. Slight irregularities in the surface seem to be primarily the result of differential compaction over basement highs. The AII unconformity slopes north-northwest toward the deep Angola Basin from its shallowest point at the base of the Walvis Ridge.
Unit 3. Unit 3 is an almost transparent sequence that overlies the high-amplitude reflection from the top of Unit 2 (Fig. 13). It is subdivided by a very discontinuous, low-amplitude seismic unconformity identifiable throughout much of the area (Fig. 7, DPT 190 at $6.9 \mathrm{~s}$ ). Below this unconformity, low-amplitude, high-frequency reflectors are discontinuous but appear to be subhorizontal to slightly hummocky. On north-south profiles, the reflectors onlap the dipping top of Unit 2 (Fig. 14, line AM-30). On east-west profiles, the lower boundary of Unit 3 tends to be more horizontal, and Unit 3 reflectors are concordant, onlapping only where there is underlying topography (Fig. 14). In several lows and at the northern end of the study area, basal reflectors are semi-continuous and of moderate amplitude (Fig. 7, DPT 210-297, and Fig. 9, FLD 1100-1370). Above the mid-sequence unconformity on east-west profiles, Unit 3 reflectors are either concordant or gently slope to the west (Fig. 14). On north-south profiles, reflectors onlap to the south (Fig. 14), except for a 16-km segment on line 


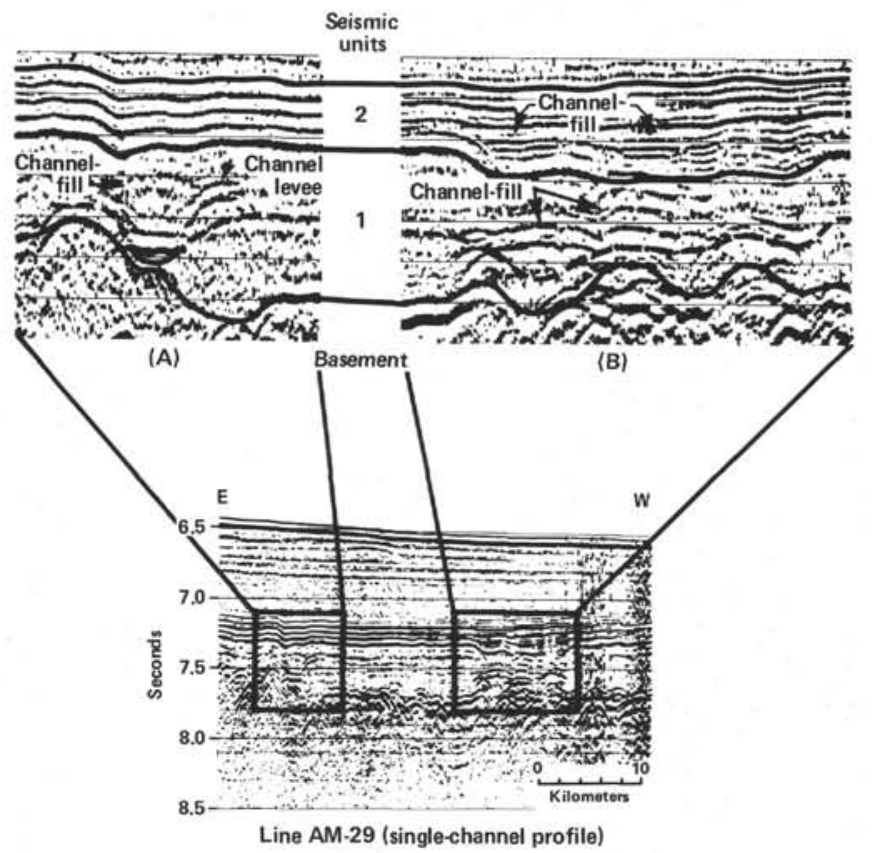

Figure 10. Single-channel, true-amplitude display of line AM-29 showing channel-fill facies in Units 1 and 2 . The higher-amplitude reflections from the complex and onlap channel-fill sediments make them easily identifiable on a true-amplitude display. The reflector forming the base of the channels in Unit 1 is a minor unconformity that can be followed with difficulty throughout most of the Site 530 survey area.

AM-36 where they appear to diverge basinward (Fig. 7, DPT 140-210).

The isopach map shows that Unit 3 thins or pinches out against the Walvis Ridge and thickens towards the deep Angola Basin (Fig. 17). Local variations in thickness occur, probably as a result of infilling of Unit 2 topography and continuing differential compaction over basement highs. Assuming a $1.65 \mathrm{~km} / \mathrm{s}$ interval velocity (see Musgrove, 1982), the unit thickens from less than $80 \mathrm{~m}$ at the base of the ridge to over $330 \mathrm{~m}$ at the northern boundary of the site survey area about $60 \mathrm{~km}$ away.

The only trend apparent in Unit 3 is a rapid decrease in reflection amplitude upward, resulting in a largely reflection-free response near the top of the unit. The top of Unit 3 is a northwest-dipping surface that slopes smoothly and gently into the deep basin (Fig. 18). This surface is formed by two distinct unconformities (Fig. 19). The older unconformity represents the end of Unit 3 deposition. The younger, angular unconformity is the result of channeling processes operating at the foot of the Walvis Ridge after Unit 3 time, and it cuts into the older unconformity at several locations (Fig. 7, DPT 15-60, and Figs. 18 and 19).

Unit 4. Unit 4 is characterized by moderate-amplitude, discontinuous, subparallel or hummocky to lenticular reflections that onlap, downlap, and parallel the top of Unit 3. On east-west profiles, several trends in this unit are apparent. Along the base of the Walvis Ridge, reflections are chaotic (Figs. 7, 19). About $30 \mathrm{~km}$ north of the ridge, a more continuous, hummocky facies is predominant (Fig. 9). In one location, the base of the hummocky facies is composed of a series of mounds 2$4 \mathrm{~km}$ across that appears to onlap to the east (Fig. 20). Even farther north, reflection continuity increases and subparallel reflectors slope gently to the west.

On north-south profiles near the Walvis Ridge, Unit 4 reflectors are subparallel, continuous and slope to the north (Figs. 7 and 19). In contrast, about $35 \mathrm{~km}$ farther

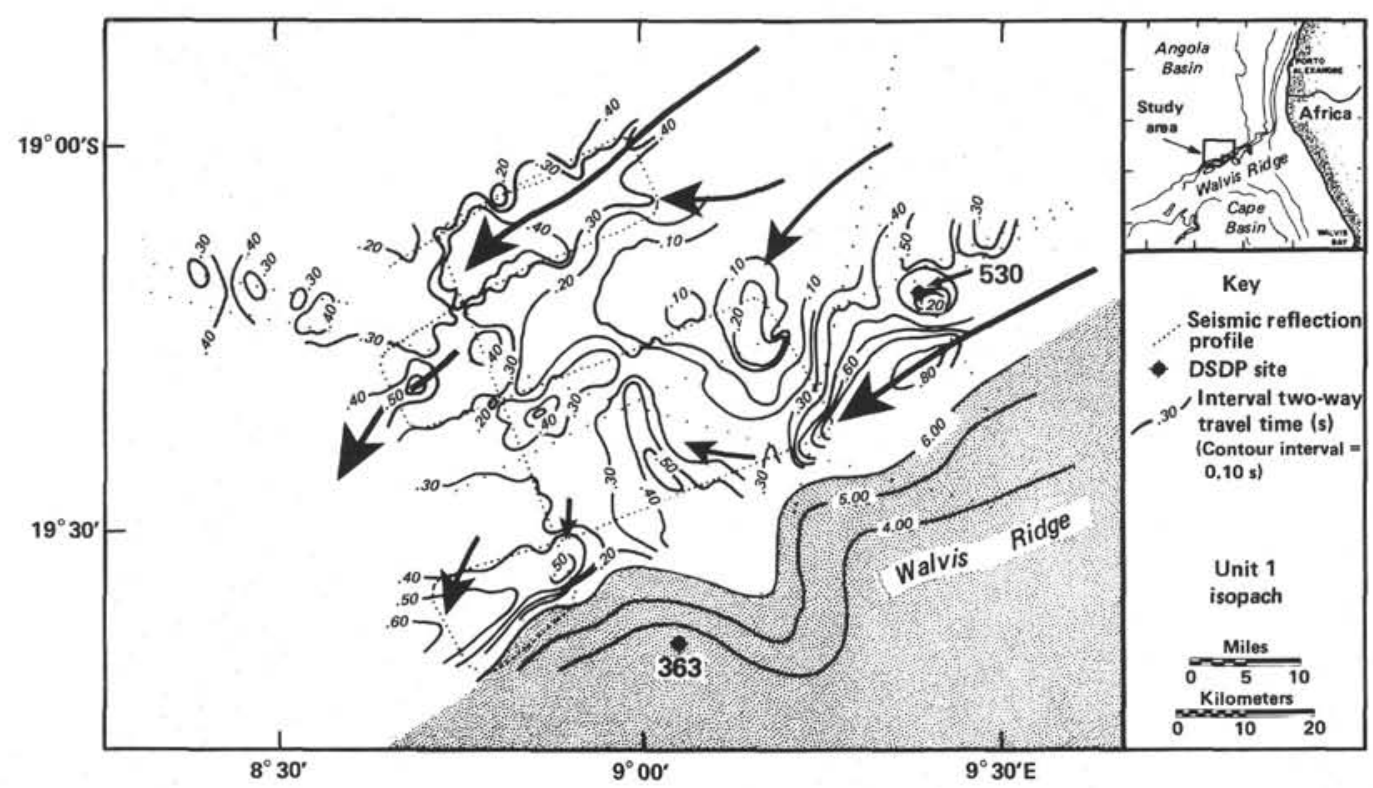

Figure 11. Isopach (in two-way travel time) of Unit 1. Assumes an interval velocity $\left(V_{i}\right)$ equal to $2.66 \mathrm{~km} / \mathrm{s}$ and an average thickness $(t)$ equal to $400 \pm 130 \mathrm{~m}$, although wide variation occurs as a result of the preferential infilling of basement lows and differential compaction over the basement topography. Arrows indicate the direction of sediment transport into the study area during Unit 1 time. Arrow size is roughly proportional to the amount of sediment transported and was estimated by the patterns of downlapping reflections and locations of maximum travel-times. 


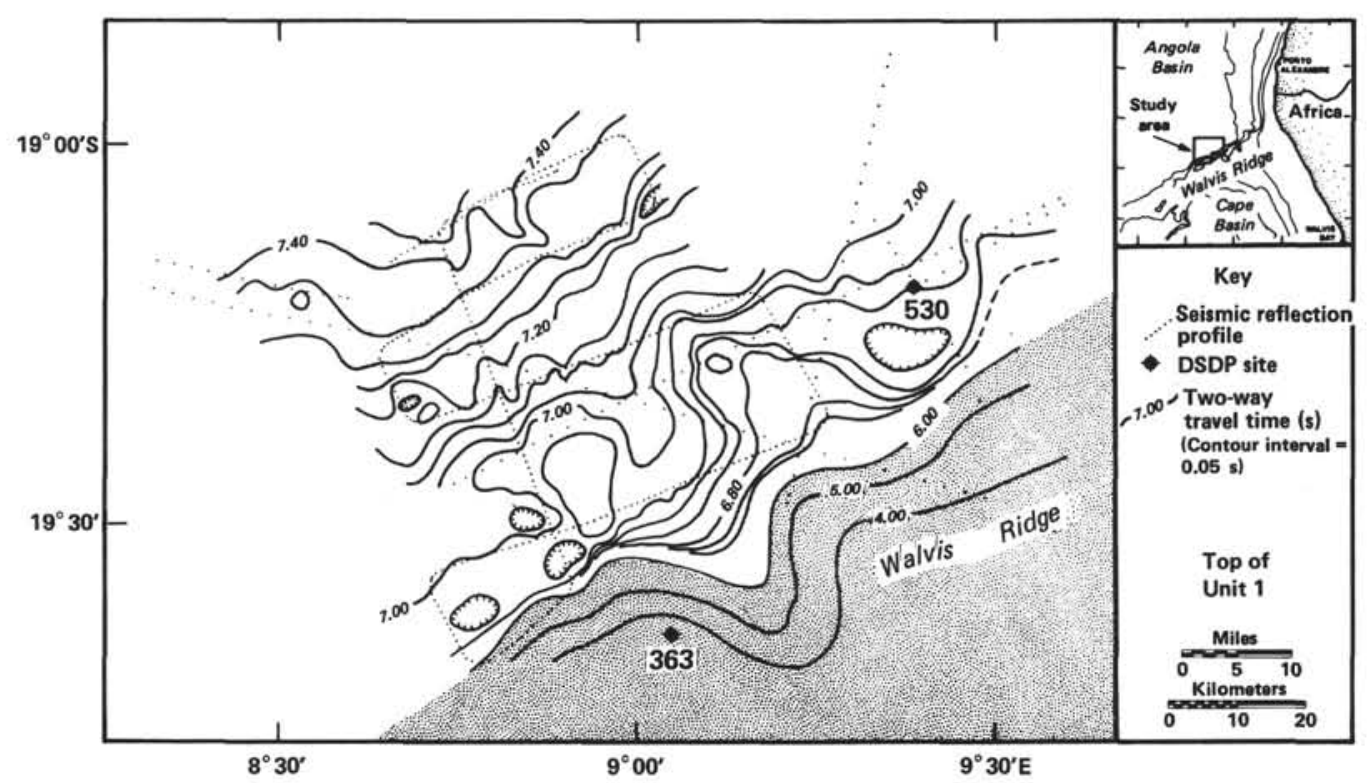

Figure 12. Depth to the top of Unit 1 (in two-way travel time). The unconformity surface exhibits as much as $0.3 \mathrm{~s}$ of relief as a result of incompletely filled basement lows and thinly draped basement highs. Additional topography developed as a result of differential compaction. The surface resembles a smoothed version of the top of acoustic basement (see Fig. 5).

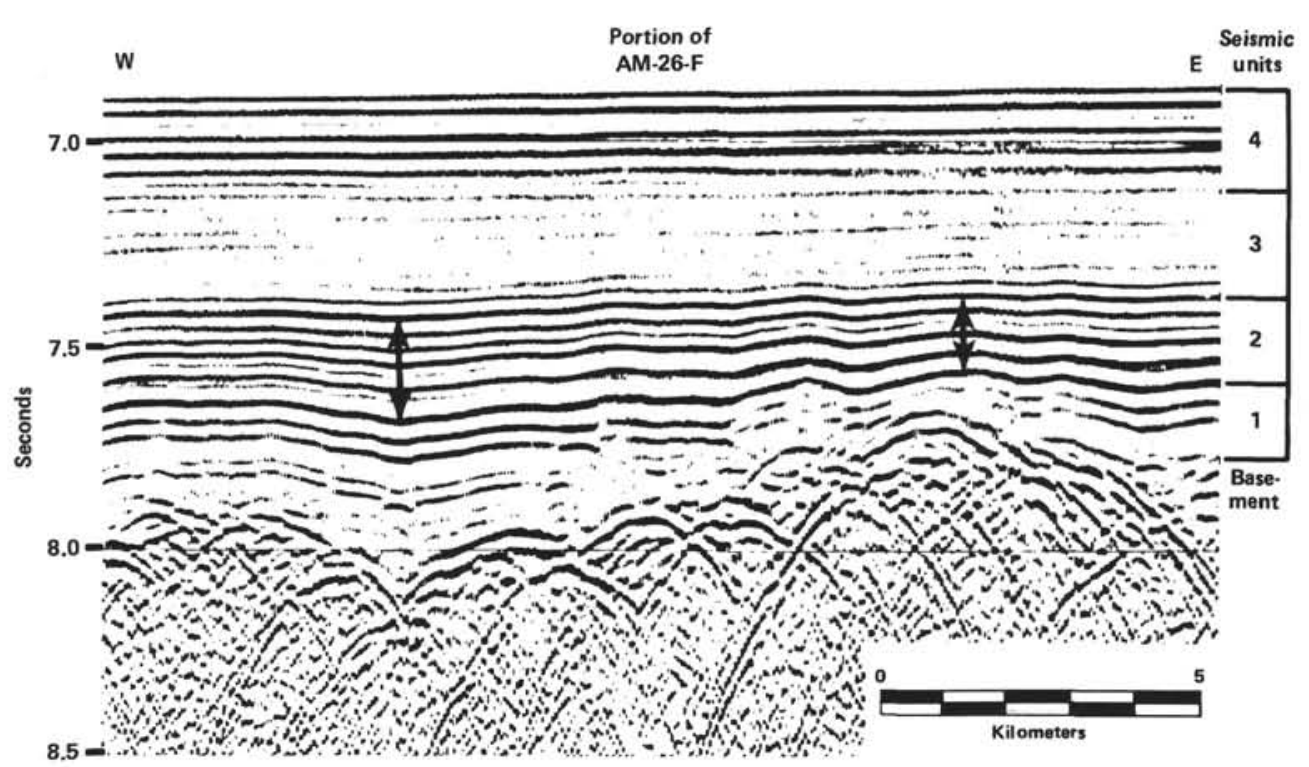

Figure 13. Portion of line AM-26-F, located about $50 \mathrm{~km}$ west-northwest of the study area, showing reflection characteristics of the four seismic units. Note the high-amplitude parallel reflectors and the imitation of basement topography characteristic of Unit 2. The arrows indicate a $25 \%$ differential in Unit 2 thickness because of compaction over basement topography.

north Unit 4 is composed of broad, onlapping mounds that slope both to the north and south (Figs. 21 and 7, DPT 190).

Unit 4 contains two minor unconformities most visible at the base of the Walvis Ridge (Fig. 19). The younger of these two unconformities cuts into the older unconformity and forms the base of a basinward-prograding channel-fill sequence. This channeling occurs in the same location as earlier erosion that removed a portion of Unit 3 (Fig. 19). About $25 \mathrm{~km}$ to the east, Unit 4 reflectors form at least two sequences of complex-fill
(Fig. 22). This cut-and-fill can be tied to a valley in the Walvis Ridge escarpment and probably represents erosion at the base of the ridge which is continuing at the present time.

\section{DISCUSSION}

\section{Basement}

Possible origins for the surface structure of the oceanic basement in the Angola Basin include inherited tectonic grain from both the mid-ocean ridge and frac- 


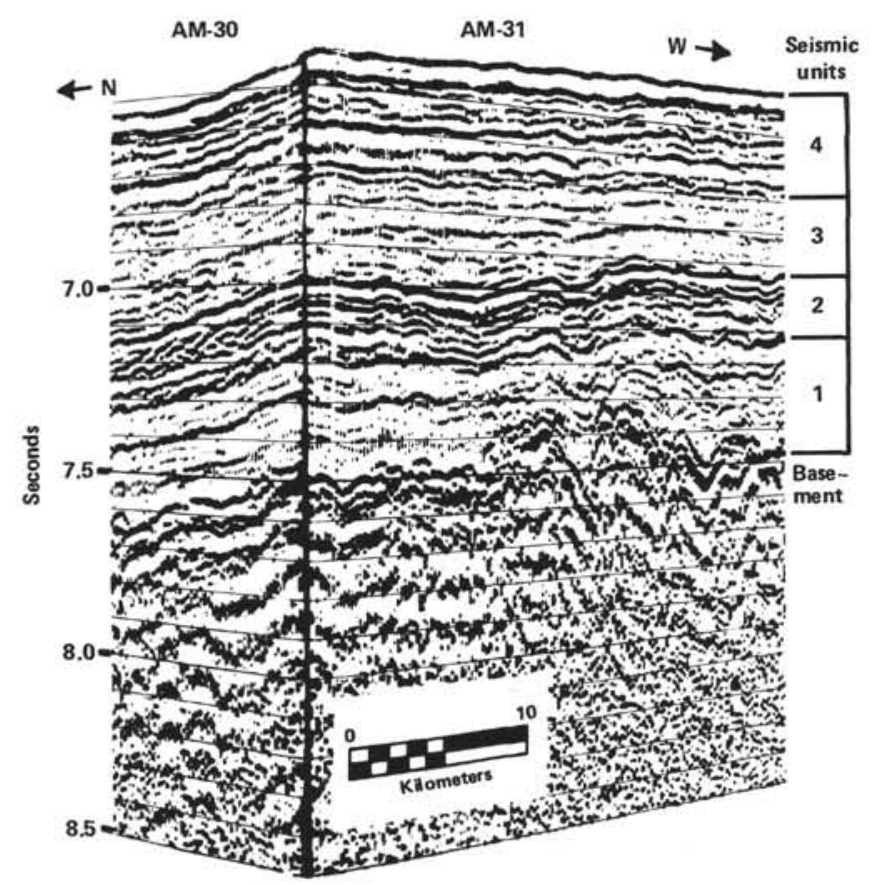

Figure 14. An isometric view looking toward the northwest of the intersection of lines AM-30 and AM-31 showing reflection characteristics of the four seismic units about $32 \mathrm{~km}$ from the base of the Walvis Ridge. Note the sigmoidal clinoforms in Unit 2 on line AM-30 and the corresponding wavy, subparallel reflectors on line AM-31. Unit 3 onlaps Unit 2, indicating that the topography at the top of Unit 2 was largely formed before the onset of Unit 3 deposition. A minor unconformity dividing Unit 3 is visible just above $6.9 \mathrm{~s}$ at the line intersection. Unit 4 reflectors are hummocky and discontinuous on seismic lines parallel to the Walvis Ridge (AM-31), but appear semi-continuous and subparallel on lines perpendicular to the ridge (AM-30). ture zones purportedly responsible for the orientation of the Walvis Ridge (LePichon and Hayes, 1971; Francheteau and LePichon, 1972; Dingle and Simpson, 1976; Kumar, 1979). By plotting the ridge axis and fracture zone trends on the depth to basement map (Fig. 4), it is clear that the dominant north-northwest topographic grain parallels the local paleo-Mid-Atlantic Ridge, which is generally perpendicular to the strike of the Walvis Ridge (Pitman et al., 1974). The structure style of the basement is similar to the morphology of modern spreading centers (see, for example, Ballard and van Andel, 1977; Ballard et al., 1979; and Sleep and Rosendahl, 1979).

The proximity of fracture zones has little apparent influence on the structure of Angola Basin oceanic crust except within 10-12 km of the base of the Walvis Ridge escarpment. A narrow, $0.4 \mathrm{~km}$-deep trough on AM-36 (Fig. 6) and a broader, $0.25 \mathrm{~km}$ depression on AM-34 (Fig. 8) may both be the result of faulting associated with fracture zones along the base of the ridge. As previously indicated, the actual boundary between the Walvis Ridge and the Angola Basin also appears to be a fault plane (Fig. 6). Based on the pattern of reflector terminations, this fault dips $9-10^{\circ}$ to the north-northwest. In comparison, the exposed face of the Walvis Ridge escarpment slopes basinward at about $8^{\circ}$ (Fig. 1).

\section{Stratigraphic Units}

All four of the seismic units characterizing the stratigraphy of the southeastern Angola Basin are distinctly different, representing a variety of sediment types, depositional processes, and environmental settings.

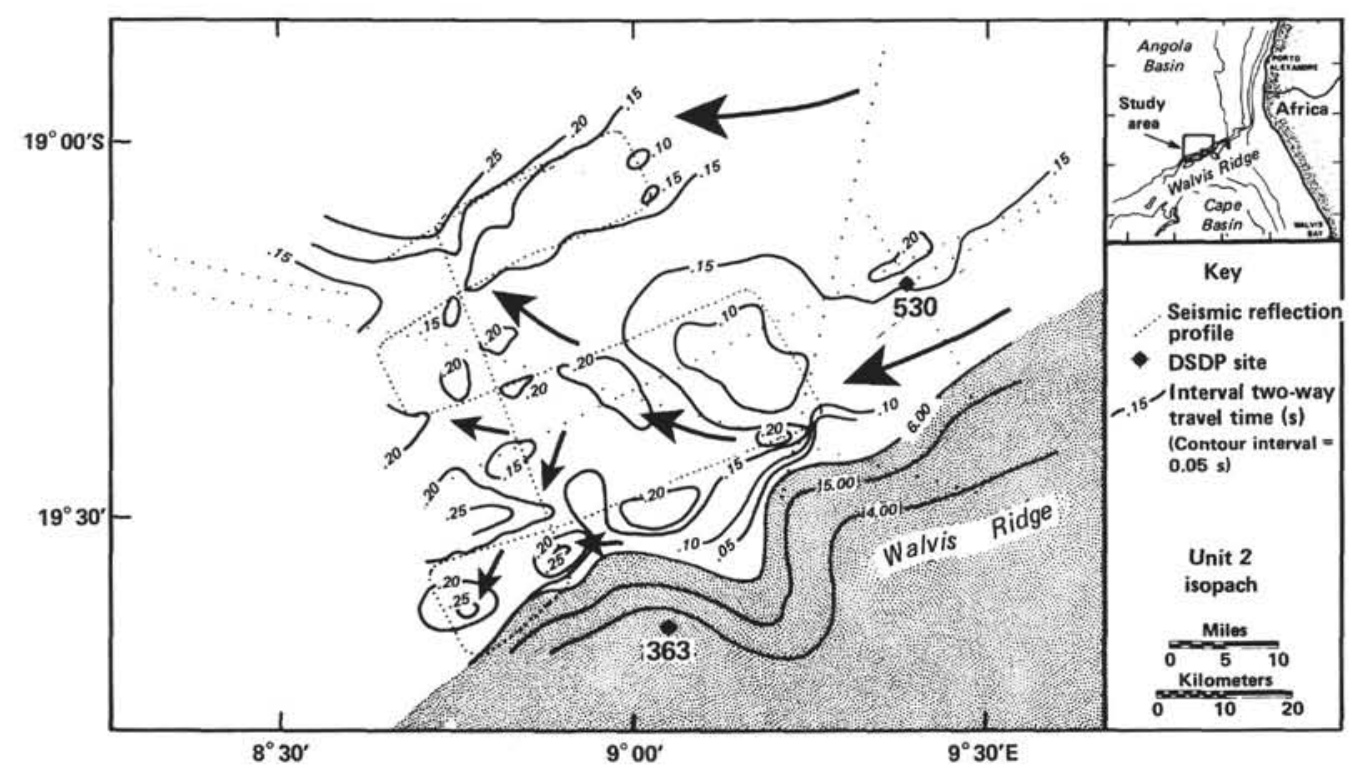

Figure 15. Isopach of Unit 2. Assuming $V_{i}=2.37 \mathrm{~km} / \mathrm{s}$ (from stacking velocities), average $t=240 \pm 60 \mathrm{~m}$ throughout the southeastern Angola Basin. Unit 2 thins over basement highs (see Fig. 13) and in the direction of the Walvis Ridge. The unit may pinch out along a valley in the escarpment, but there is no evidence that this valley was an active erosional channel during Unit 2 deposition. Arrow size is proportional to the amount of sediment transported and was estimated by the patterns of downlapping reflections and locations of maximum travel-times. 


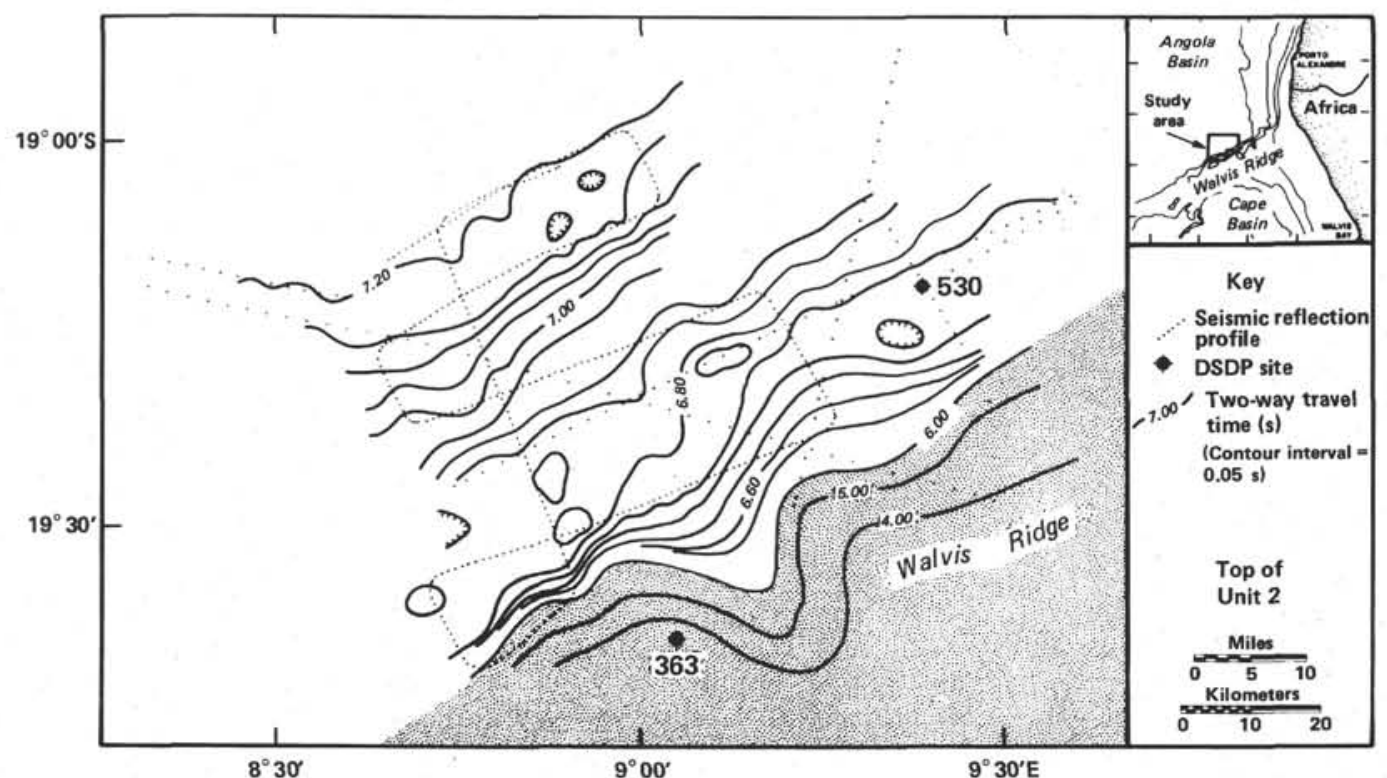

Figure 16. Depth to the top of Unit 2, which slopes away from the base of the Walvis Ridge. Slight irregularities in the surface are primarily the result of differential compaction over basement highs.

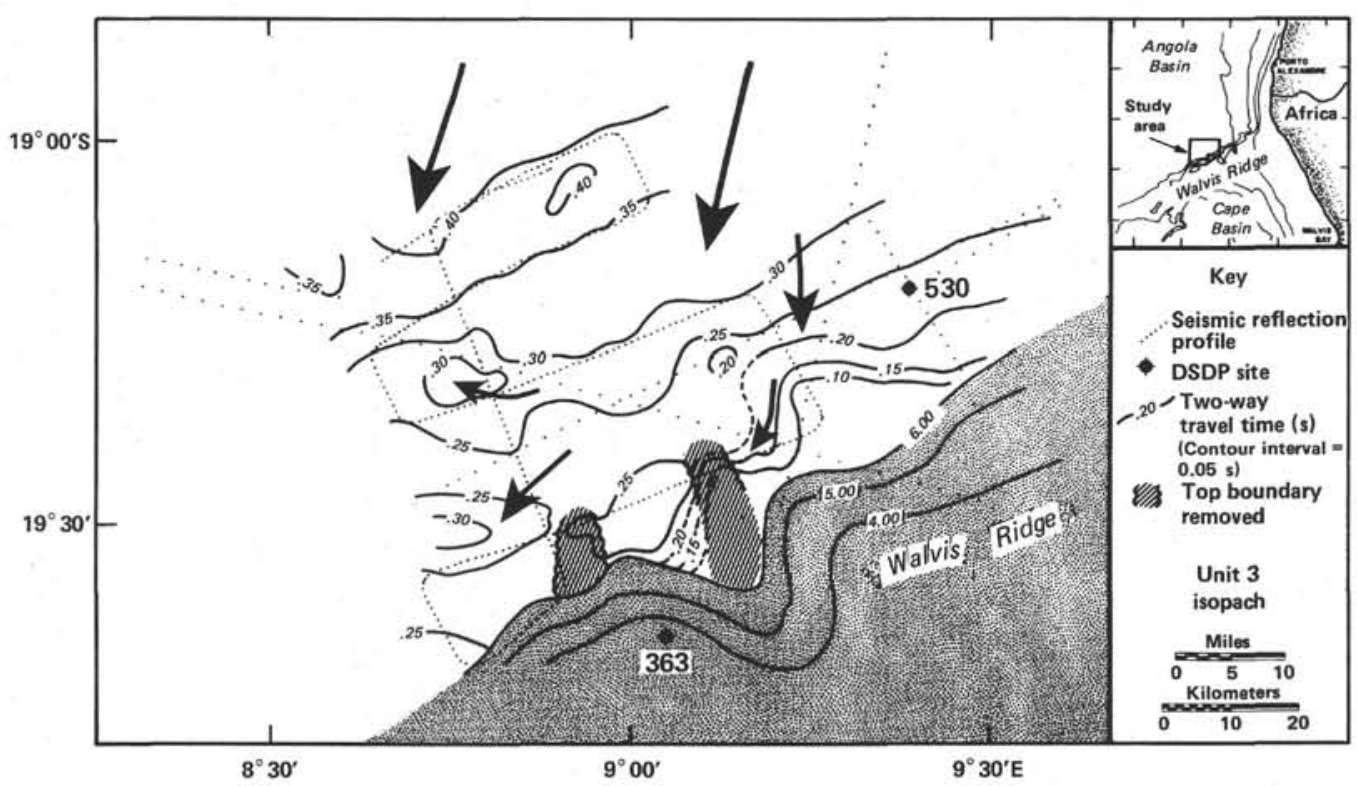

Figure 17. Isopach of Unit 3. Assuming $V_{i}=1.65 \mathrm{~km} / \mathrm{s}$ (from stacking velocities), the unit thickens from less than $80 \mathrm{~m}$ at the base of the ridge to over $330 \mathrm{~m}$ at the northern limit of the study area about $60 \mathrm{~km}$ away. Hachured area indicates where part of the unit has been removed by post-Unit 3 erosion. Arrow size is proportional to the amount of sediment transported and was estimated by the patterns of downlapping reflections and the locations of maximum travel-times.

Unit 1 . The wide variety of reflection patterns in Unit 1 indicates that several different depositional processes were active in the southeastern Angola Basin during Unit 1 time. The way in which the base of Unit 1 onlaps oceanic basement, together with its tendency to fill topographic lows, suggests deposition by turbidity currents. The slightly hummocky but discontinuous reflections comprising the lower half of Unit 1 could represent the distal lobes of a deep-sea fan complex com- posed of turbidites, slumps, and hemipelagic deposits. Divergent reflectors in the lower half of the unit also indicate that there was continued subsidence of basement lows relative to highs during deposition.

The low-amplitude, discontinuous reflections which generally overlie oceanic basement imply that the first sediments deposited in the Angola Basin were relatively homogeneous. However, occasional high-amplitude reflectors in basement lows suggest one or more brief 


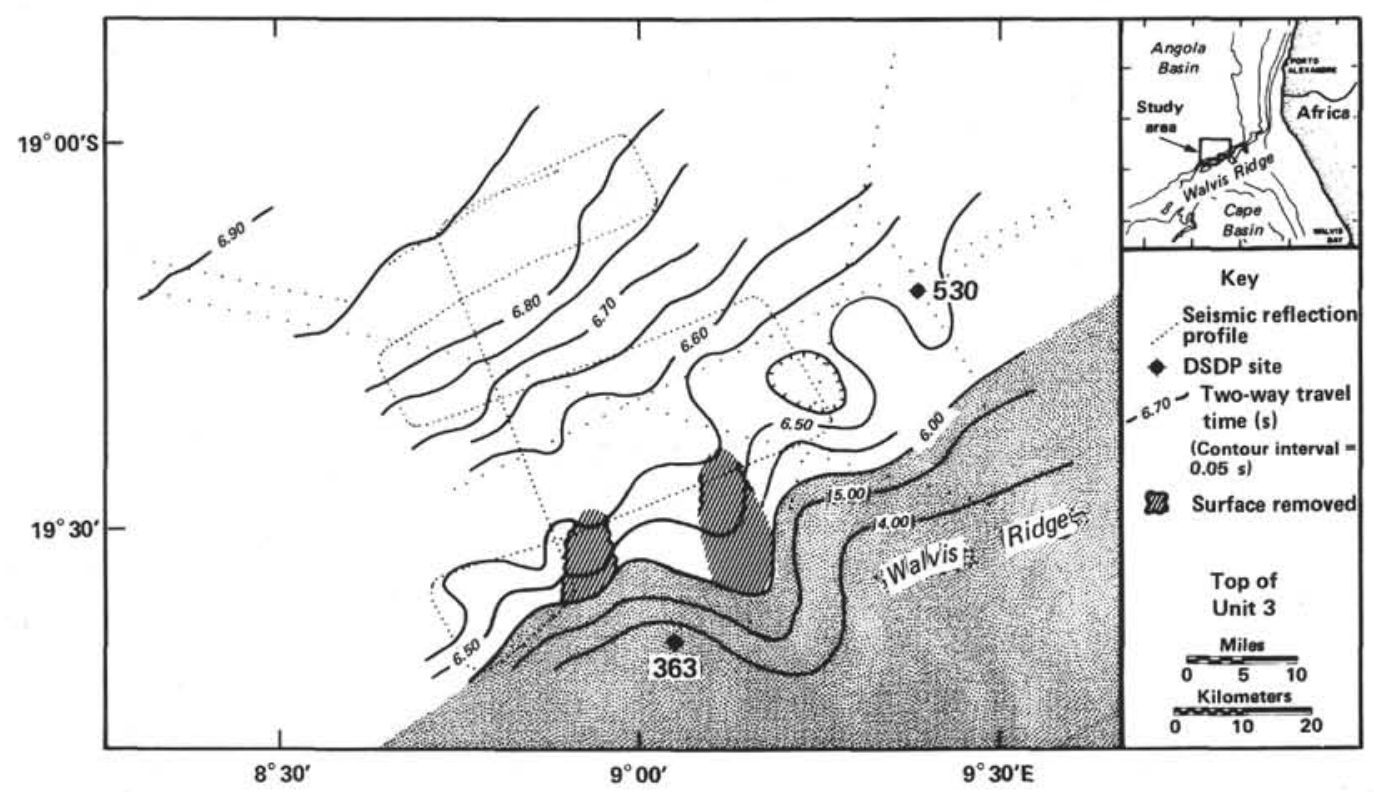

Figure 18. Top of Unit 3, showing that the surface slopes gently basinward away from the Walvis Ridge. The surface is formed by two distinct unconformities. The older unconformity, representing the end of Unit 3 deposition, is dissected by a younger angular unconformity in several places (hachured).

pulses of very different material, perhaps small amounts of calcareous sediment flushed from the nearby shallow portion of the Walvis Ridge.

Increased continuity of reflections upward in Unit 1 may be the result of an increase in sediment supply. An associated increase in reflection amplitude implies a higher velocity-density contrast perhaps indicative of different sediment types. Both characteristics suggest a more proximal source area.

The minor unconformity dividing Unit 1 suggests the development of a system of fan valleys which channeled coarser-grained sediments into the study area by bypassing the proximal fan. This is supported by the presence of buried channels whose bases appear to correlate with the unconformity. The channels display well-developed levees (Fig. 10) and some component of lateral migration, both of which are typical of submarine fan valleys (Reineck and Singh, 1973). The channels are observed on both north-south and east-west profiles, so cut-andfill occurred as a response to local topography. The reflections overlying the channels are discontinuous, irregular and mounded, and probably represent deposits formed by higher velocity turbidity currents (Sangree and Widmier, 1977).

The southward downlapping or onlap-fill at the base of the Walvis Ridge is in contrast to the more dominant west-northwest-dipping reflections of Unit 1 . This facies must reflect local channeling (Fig. 8) caused by bottom-flowing currents diverted by or flowing along the base of the Walvis Ridge escarpment.

Sediment provenance is difficult to determine from the isopach map alone (Fig. 11), since Unit 1 thins and thickens with no obvious pattern. However, the geometry of downlapping reflectors points to a predominant source located in the direction of the African continental margin (Fig. 11). Deviation from this direction of sediment transport is indicated locally by channel-fill and the presence of divergent reflections sloping off basement highs in all directions.

Unit 2. Unit 2 reflectors record a change from the relatively high-energy depositional environment at the end of Unit 1 time to a lower energy system. The onlap fillin channels (Fig. 10), the onlapping of previous topography (Fig. 9), and high amplitude reflections all suggest that Unit 2 was deposited by relatively low-velocity turbidity currents interbedded with hemipelagic clay and silt (Sangree and Widmier, 1977). The sigmoid-progradational facies (Fig. 14) is also considered typical of lowenergy turbidity current deposition of fine-grained clastics and indicates some sort of deep-water current action. Such currents active at the base of the Walvis Ridge are responsible for the southward prograding reflectors in Unit 2 near the escarpment (Fig. 8).

In the upper part of Unit 2, low-energy gravity flows over gentle topography give way to a more pelagic depositional environment marked by very continuous, evenly spaced reflectors. However, high amplitudes indicate contrasting lithologies, probably coming from different source areas.

Unit 2 appears to have been deposited as a series of broad submarine fan lobes, but the source for Unit 2 sediments is difficult to determine because of the various directions indicated by the seismic stratigraphic patterns. The northward-dipping, semi-continuous reflectors and clinoforms, together with the channel-fill deposits (Fig. 10), point to a turbidite source located on the Walvis Ridge. The southward thinning of Unit 2 could be the result of turbidite sediments from the Walvis Ridge bypassing the foot of the ridge to accumulate in the deep Angola Basin. Unfortunately, the absence of major north-south canyons on the escarpment argues against a ridge source. The fact that the top of the unit 


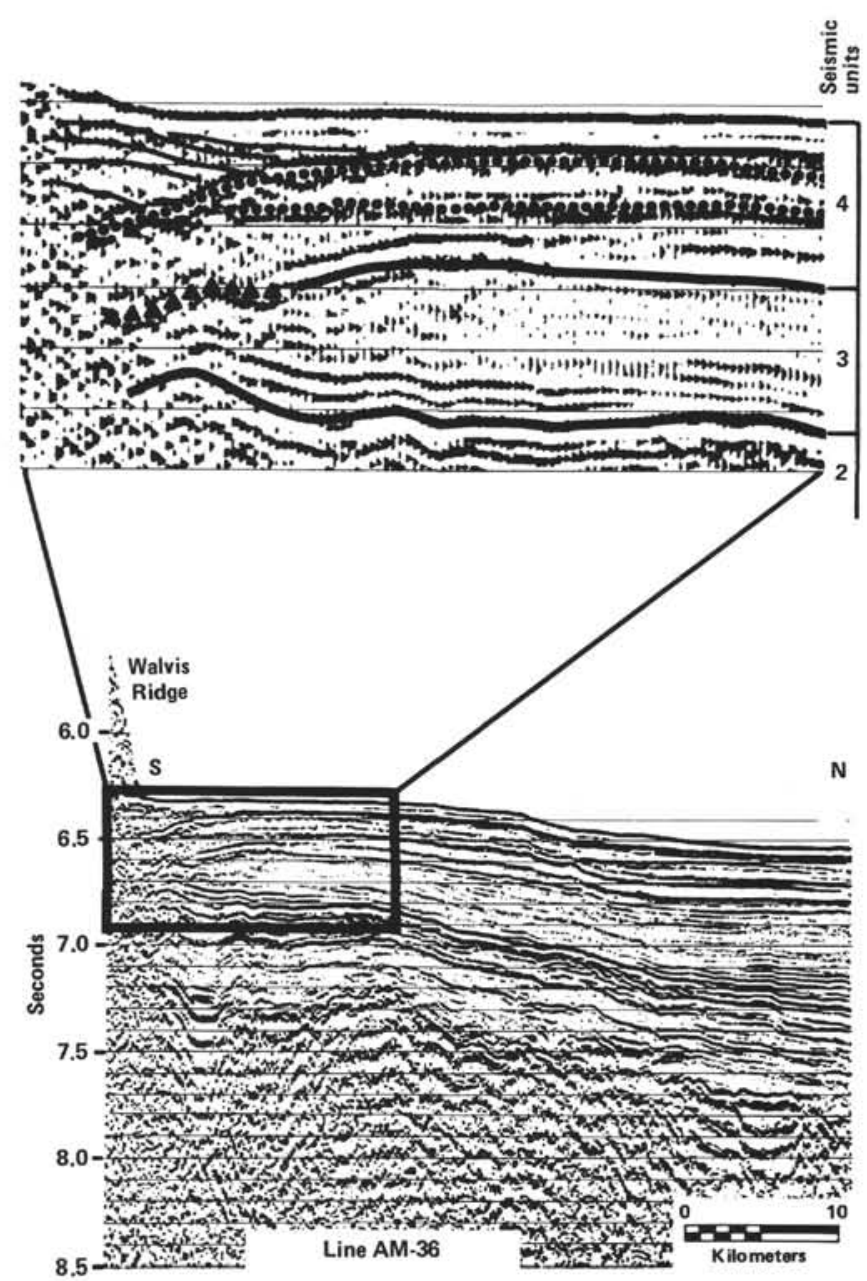

Figure 19. Detail of line AM-36 showing Units 3 and 4 at the base of the Walvis Ridge. AM-36 is perpendicular to a small valley in the ridge associated with erosional processes active following the deposition of Unit 3. A portion of the unconformity forming the top of Unit 3 has been removed by this later erosional event (triangles; see Fig. 18). Unit 4 contains two minor unconformities (dots) representing at least two periods of erosion. As shown here, the younger erosional event has dissected the older unconformity and removed a $4-\mathrm{km}$ wide piece of the underlying section nearest the ridge. Overlying reflectors (thin lines) appear to prograde basinward.

mimics a major re-entrant in the ridge (Fig. 16) results from differential compaction (Fig. 5) and not from depositional input from the south.

Another possibility is that Unit 2 sediments came originally from the African continental margin to the east, and were then turned to the north by the Walvis Ridge. Westward-dipping reflectors near the base of the escarpment support this contention. At the same time, progressive infilling of the basin resulted in some onlap of Unit 2 reflectors from the north (Fig. 7).

Unit 3. Unit 3 was deposited by low-energy turbidity currents transporting compositionally uniform sediments into a quiet basinal environment. The sharp contrast between the seismic stratigraphy of Units 2 and 3 indicates that a major change in Angola Basin depositional environment occurred following Unit 2 deposition. In fact, the sudden decrease in reflection strength across the Unit 2/Unit 3 boundary makes this unconformity easily identifiable throughout the entire southern Angola Basin (horizon "AII"; Emery et al., 1975; Bolli, Ryan et al., 1978; Hay, Sibuet et al., 1981). Unlike Unit 2, Unit 3 is characterized by a marked lack of both erosional channeling and high-angle stratification. Unit 3 is also unusual in that, although the sediments appear acoustically to have been deposited in a low-energy, pelagic environment, there is little draping of topography normally characteristic of such deposits. Even at the base of the Walvis Ridge, the progradational facies of Units 1 and 2 has been replaced by gentle onlapping in Unit 3.

The source of Unit 3 sediments appears to have been to the northeast (Fig. 17). The well-defined onlap to the south indicates a source located farther north than for Units 1 and 2. Perhaps the northward shift was a result of diminished sediment supply from nearer sources on the continental margin.

While the seismically transparent nature of Unit 3 indicates a largely homogeneous composition, the presence of onlapping and hummocky reflections suggests that Unit 3 was deposited primarily by turbidity currents. Draping reflections are absent, so pelagic deposition must have been relatively unimportant.

Unit 4. The Unit 3/Unit 4 boundary represents a rapid change in depositional environment to higher energy, which results in an increase in reflector amplitude in Unit 4. Unit 4 is the first seismic sequence to show a definite seismic stratigraphic trend with respect to the Walvis Ridge. Its reflections grade from chaotic and channeled at the base of the ridge to hummocky and then subparallel basinward. Apparently, Unit 4 was deposited in part as a series of slumps and flows coming from the Walvis Ridge. The small, prograding mounds present at the base of the unit suggest coalescing lobes of a submarine fan deposit at the foot of the ridge, while the presence of two erosional channels indicates that at least some of these sediments bypassed this region. However, the absence of channeling north of AM-33 (Fig. 1) indicates that active scouring did not occur more than $10-15 \mathrm{~km}$ away from the escarpment.

The isopach map indicates that Unit 4 is composed of sediments derived from the east as well from the south (Fig. 23). The exact location of this eastern source area is not clear. Sediments may have come from either the African continental margin or from a major sediment conduit in the Walvis Ridge farther east (Fig. 24). The fact that depositional processes from the south are first apparent during Unit 4 time supports a ridge-derived source for at least part of Unit 4's sediments. Apparently, that depositional regime is continuing at the present time.

The two sediment sources indicated by the isopach map of Unit 4 suggest different modes of deposition which are reflected in the unit's seismic stratigraphy. The mounded, onlapping facies on north-south profiles could represent fan lobes formed by westward transport of debris flows from the ridge farther to the east, but ridge-derived sediments could also have reached the study area directly down small canyons. 


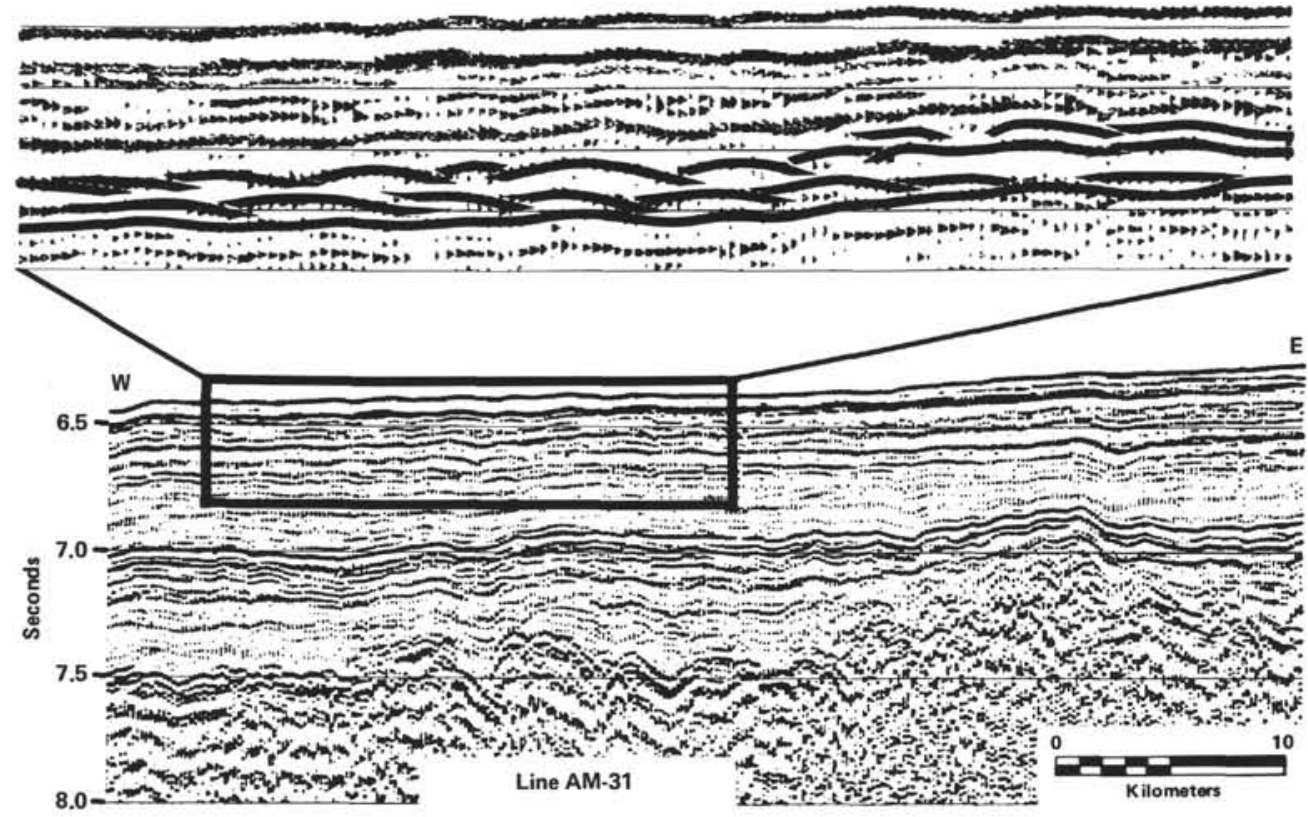

Figure 20. Detail of small (2-4 km), onlapping mounds in Unit 4 progressively prograding across the top of Unit 3. The mounds appear to onlap to the east in the direction of the African continental margin and may represent small coalescing lobes of a submarine fan, whose source was the Walvis Ridge.

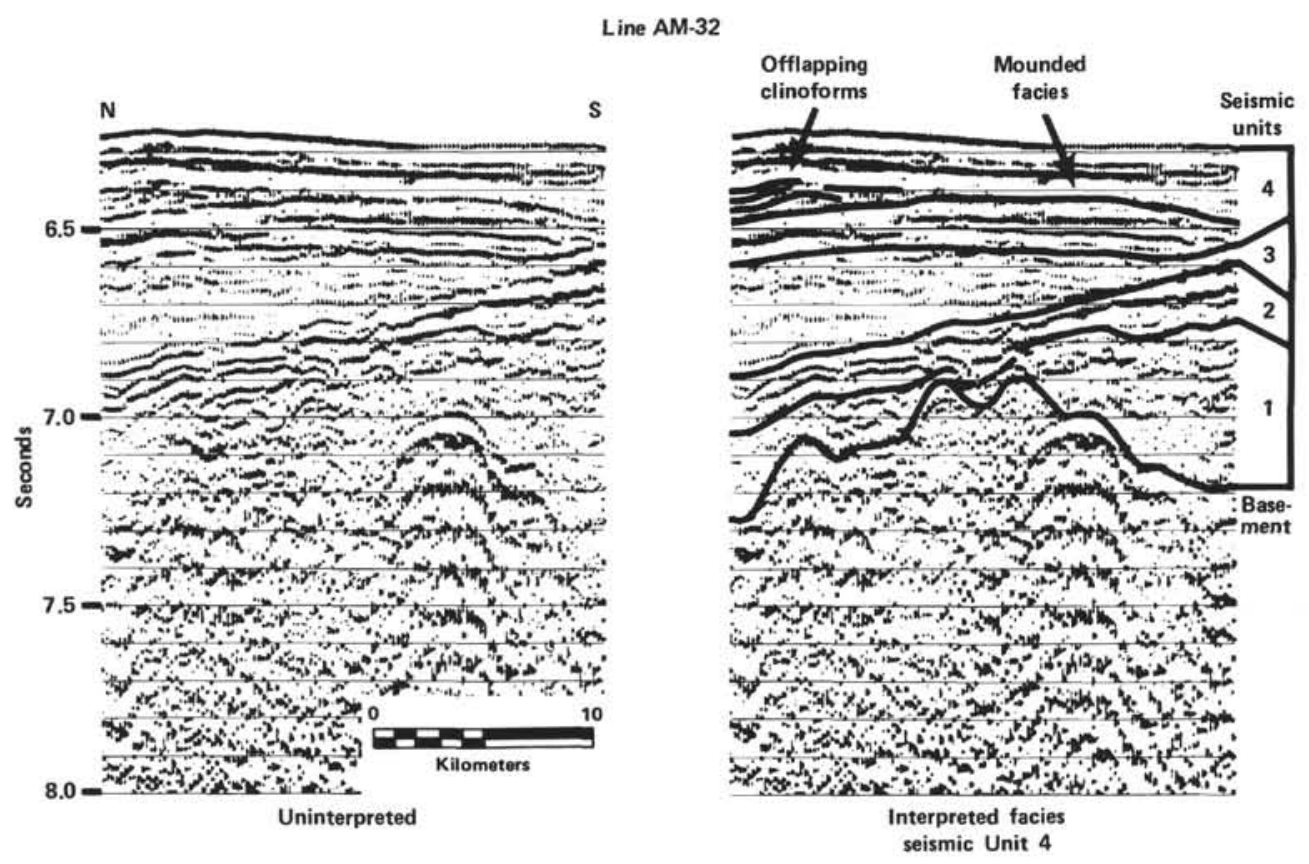

Figure 21. Line AM-32 showing the interpreted seismic units and basement surface. Seismic facies in Unit 4 have been highlighted to show a broad, mounded form bordered by offlapping clinoforms prograding northward into the basin approximately $35 \mathrm{~km}$ north of the Walvis Ridge. These facies could represent a cross-section of a large submarine fan lobe prograding to the west.

\section{Summary}

Although each of the four interpreted seismic sequences is unique, they share some common characteristics. All four were deposited primarily by gravity flows and turbidity currents (with the possible exception of the upper half of Unit 2, where pelagic drape appears to be dominant). Hummocky reflections are evident through- out, and cut-and-fill structures are seen in Units 1, 2, and 4 (Figs. 10 and 22). In Units 1 and 2, erosion and deposition concentrated at the base of the Walvis Ridge may have been the result of deep currents operating either along or perpendicular to the escarpment (Figs. 7 and 8). Each unit either onlaps or downlaps the underlying units. There is also a common tendency for reflections to become more horizontal or concordant upward within each 


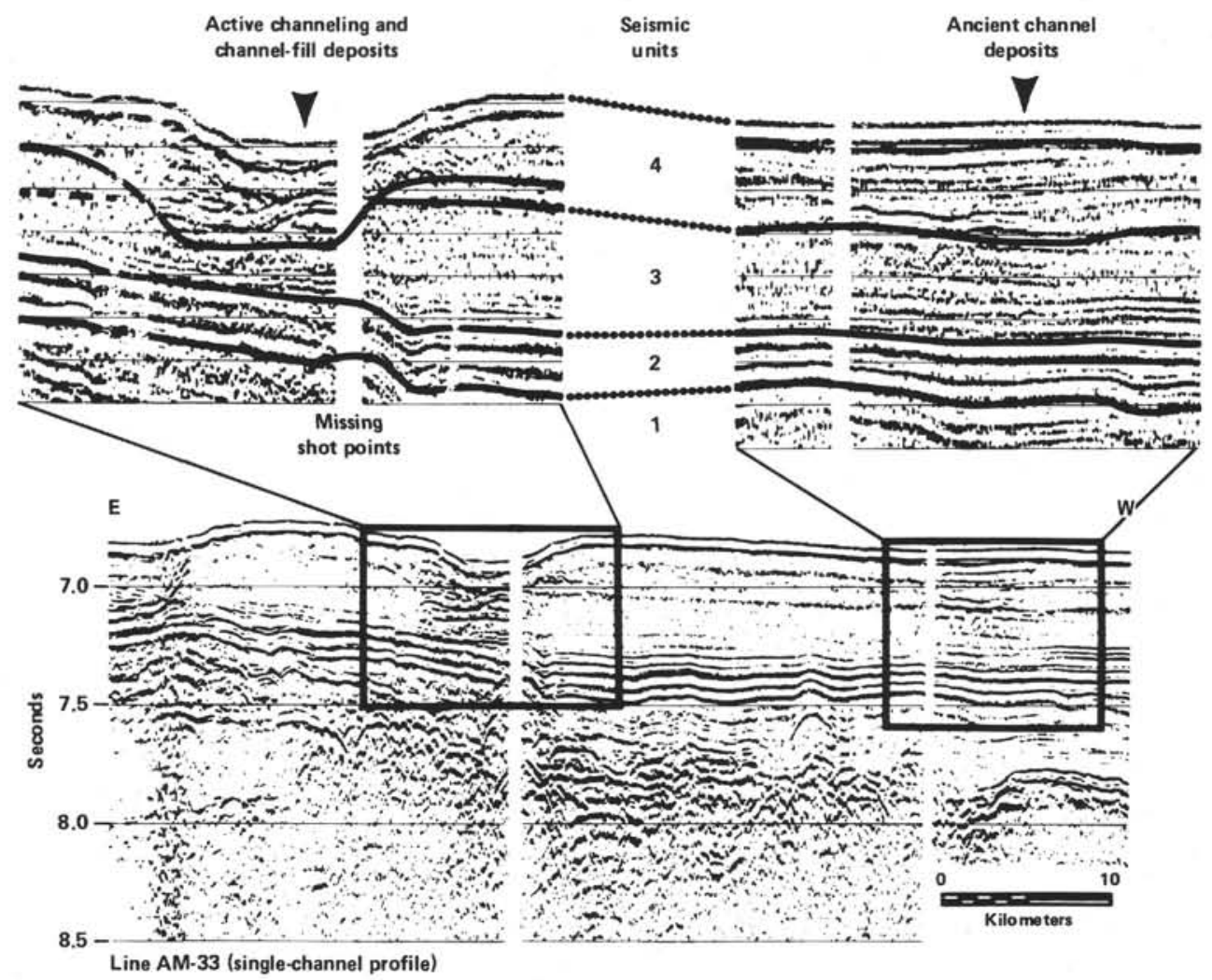

Figure 22. True amplitude display of line AM-33 near the base of the Walvis Ridge. The line crosses an area of channeling opposite a canyon in the ridge that appears to have been active since the start of Unit 4 deposition. An earlier episode of channeling is also evident at the western end of this line. At least two periods of erosion are indicated. Channel-fill deposits are easily identified on a true-amplitude display by their higher-amplitude seismic reflections. The amplitude contrast may be a result of a greater amount of compaction in the channels, higher velocity sediments composing the fill, focusing of seismic waves as a result of concave reflecting surfaces, or a combination of the above.

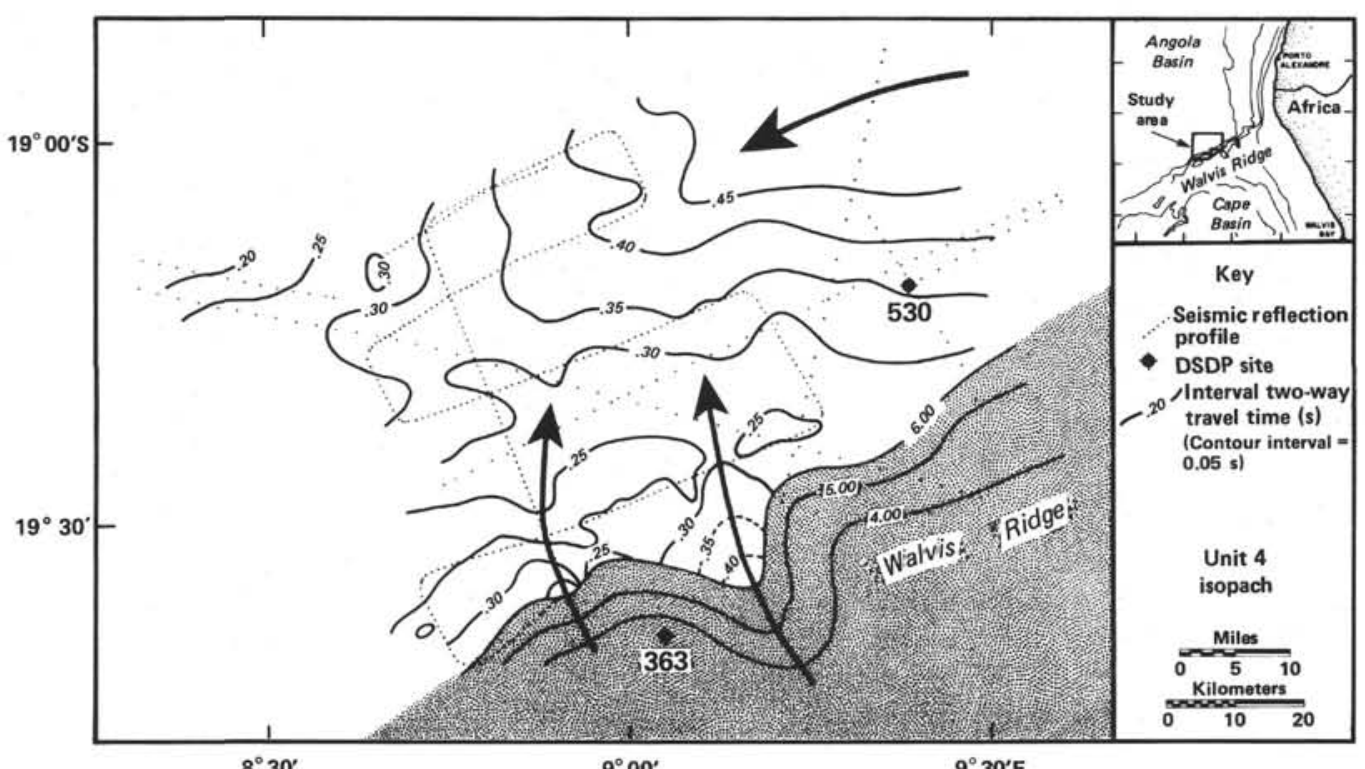

Figure 23. Isopach of Unit 4. At least two sediment sources are indicated. The arrow size is proportional to the amount of sediment transported and was determined by the patterns of downlapping reflections and the locations of maximum travel-times. The eastern source has resulted in the accumulation of over $345 \mathrm{~m}$ of sediments (assuming an average $V_{i}$ for Unit 4 of $1.54 \mathrm{~km} / \mathrm{s}$, see Musgrove, 1982) in the northeast corner of the study area, while the Walvis Ridge contributed sediments via small valleys in the escarpment. 


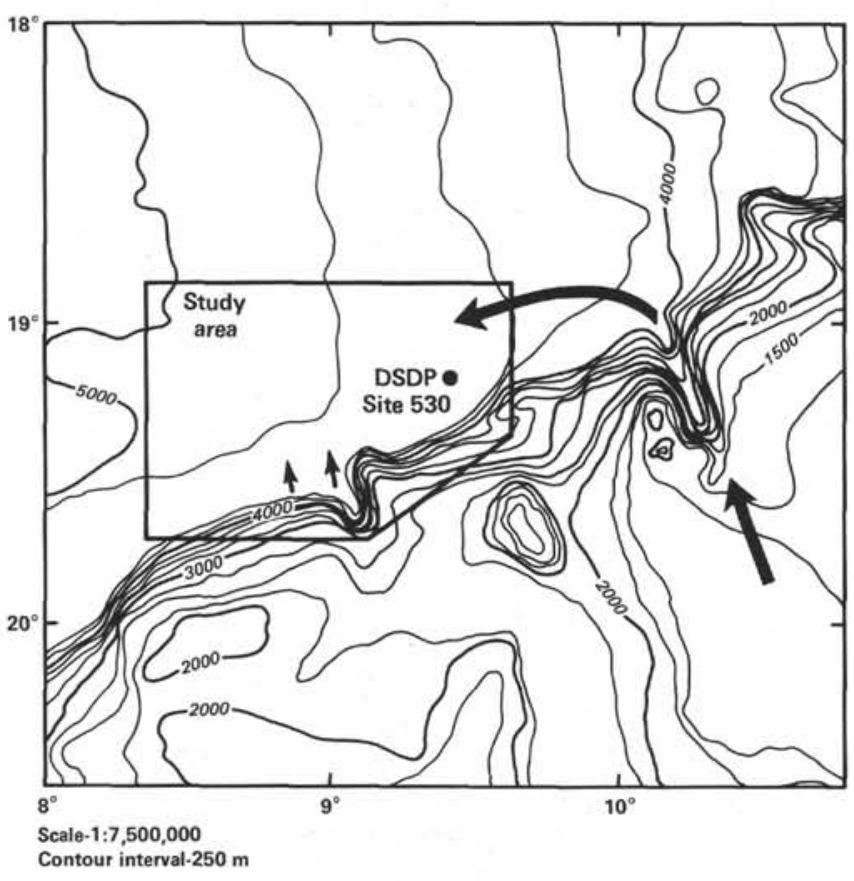

Figure 24. Proposed directions of sediment transport into the site survey area active from the onset of Unit 4 deposition to the present. Arrow size is roughly proportional to the amount of sediment transported. (Bathymetry is from P. D. Rabinowitz, pers. comm.)

seismic sequence, making it difficult to determine how much sediment has been removed by each top-bounding unconformity. Only Unit 4 is hummocky throughout. Finally, Units 1-3 all show some evidence of differential compaction over underlying topography (Fig. 13).

The isopach and structure maps of each unit show several three-dimensional trends. The Unit 1 isopach map is highly variable, the result of initial sedimentation in a topographically rough basin. No trends other than those of the previous basement structure are apparent (Fig. 11). A slight thickening to the north in Unit 2 becomes clearly evident in Unit 3 (Figs. 15 and 17). This sediment wedge may indicate that the deep Angola Basin had been largely filled by Unit 3 time, allowing sediments to onlap the edges of the basin.

With the exception of the uneven top of Unit 1, the tops of Units 2-4 are northwest-dipping surfaces (Figs. 16,18 , and 1). This suggests post-depositional tilting. In fact, divergent reflectors in Units 1 and 3 (Fig. 7) and the basinward prograding clinoforms in Unit 2 (Fig. 14) all suggest that the central Angola Basin has been subsiding at a faster rate than the southern edge of the basin next to the Walvis Ridge.

\section{GEOLOGIC HISTORY: SOUTHEASTERN ANGOLA BASIN}

The geologic history of the southeastern Angola Basin in the vicinity of Site $\mathbf{5 3 0}$ is presented as a genetic interpretation of the seismic stratigraphic results. Some references are made below to preliminary information obtained from Site 530, but the primary emphasis is on the geological significance of the geophysical data.

\section{Basement}

DSDP Site 530 is located on the Angolan continental rise about $150 \mathrm{~km}$ from the base of the continental slope and only $15 \mathrm{~km}$ from the Walvis Ridge escarpment (Figs. 1, 25). Preliminary biostratigraphy indicates a Cenomanian age (approx. 97 m.y. ago) for igneous basement at the drill site (Hay et al., 1982). By this time, some $10 \mathrm{~m} . \mathrm{y}$. following the ridge jump postulated by Rabinowitz and LaBrecque (1978), normal seafloor spreading processes were probably re-established. Therefore, the basalt sampled at Site 530 is considered here to be a typical example of the type of oceanic crust formed at a slow-spreading ridge.

The origin of the north-northwest structural trend (Figs. 4 and 5) dominating the oceanic basement morphology in the study area must have been the result of seafloor-spreading processes. First, normal faulting and tilting of blocks away from a central rift valley followed initial formation of ocean crust. Then, continued extension along these faults developed a grain parallel to the north-northwest trending ridge axis (Sleep and Rosendahl, 1979). Similar, regularly spaced ridges and troughs have been found occurring in a 20 - to $25-\mathrm{km}$ wide area along the modern Mid-Atlantic Ridge in the North Atlantic (Ballard and van Andel, 1977). Smaller irregularities are probably volcanoes or seamounts which formed on or near the ridge axis (Allmendinger and Riis, 1979; van Andel and Ballard, 1979).

Previously collected gravity data have suggested that the eastern Walvis Ridge is in local isostatic equilibrium and compensated to a depth of about $25 \mathrm{~km}$ by a lowdensity root (Goslin and Sibuet, 1975; Detrick and Watts, 1979), as opposed to the western ridge, which sits on flexured, thin crust (Detrick and Watts, 1979). A narrow, 0.4-km wide trough on line AM-36 (Figs. 1, 5, and 7) is the only evidence that we have to show local disturbance of the oceanic crust along the postulated boundary fault between the Walvis Ridge and Angola Basin (Fig. 6).

The eastern Walvis Ridge stands higher and subsides more slowly than adjacent Angola Basin oceanic basement. Basement slopes to the north-northwest away from the ridge (Fig. 5), and divergent reflectors in Units 1 and 3 (Fig. 7), and basinward-prograding clinoforms in Unit 2 (Fig. 14), all indicate that the Angola Basin has been subsiding faster than the base of the ridge since Late Cretaceous time. Our results support van der Linden's (1980) contention that the eastern Walvis Ridge is a fragment of African continent displaced during the initial opening of the South Atlantic and now covered by basic lavas extruded along boundary faults (Fig. 6).

\section{Sediments}

The stratigraphic section at Site 530 contains an almost complete record of sediment accumulation in the southern Angola Basin over the past 100 m.y. (Fig. 25). Two main types of deposits are recognized: open-ocean pelagic and hemipelagic sediments, and sediments deposited downslope by turbidity currents and debris flows (Hay et al., 1982). 


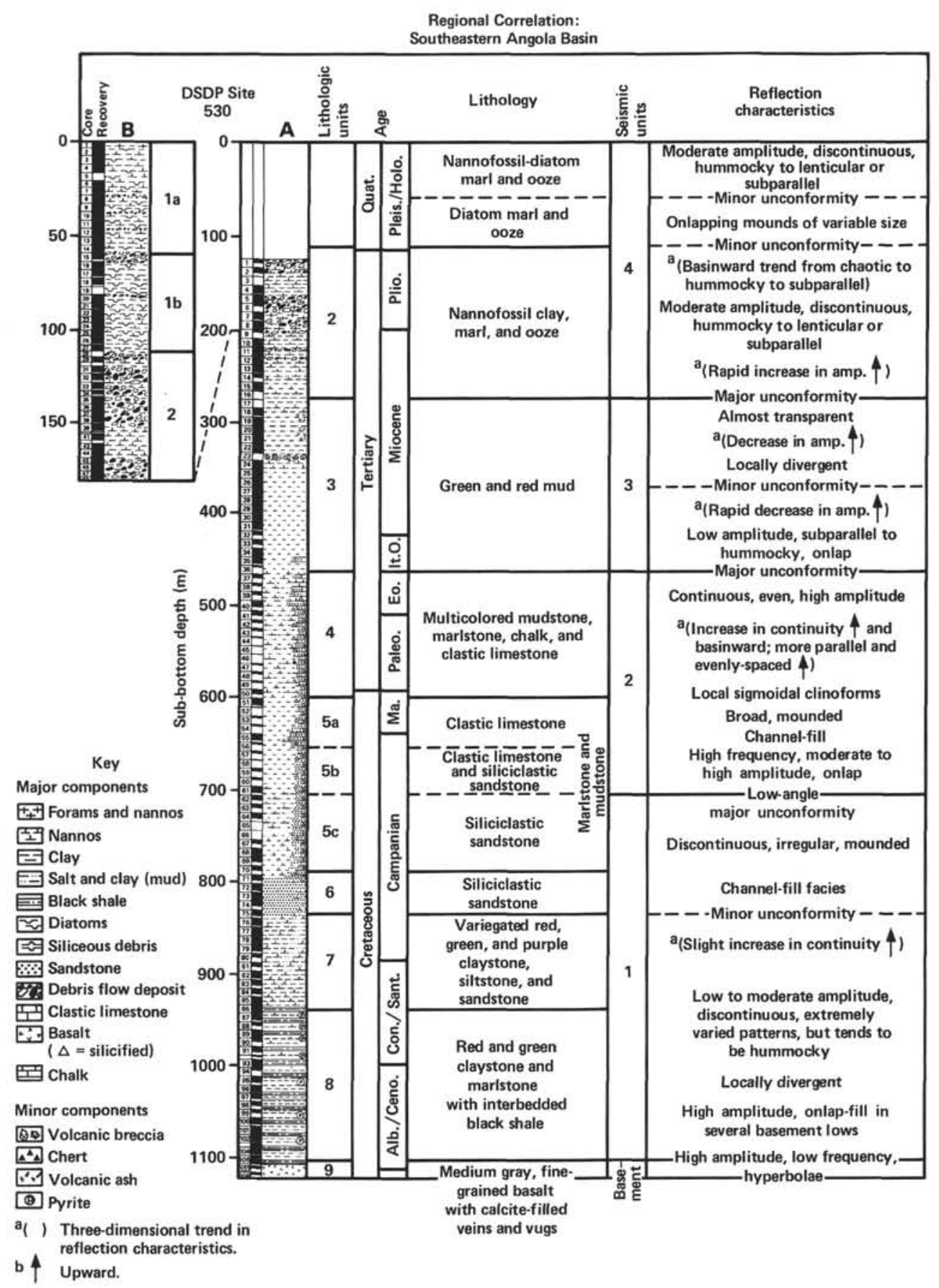

Figure 25. Stratigraphic column recovered from DSDP Holes 530A and 530B showing composition, geologic age, and preliminary unit subdivisions (Hay, et al., 1982). The four seismic stratigraphic units defined by this investigation and their corresponding acoustic characteristics are tied to the lithologies.

Seismic Unit 1 (late Albian-early Cenomanian to late Campanian). The oceanic crust at Site 530 began receiving hemipelagic sediments immediately after its creation. The first $5 \mathrm{~cm}$ of red mudstones overlying the basalt have been altered by hydrothermal activity, indicating that volcanic processes were still active when these first sediments were deposited. A small amount of carbonate and possibly volcanic debris may also have been washed from the top of the Walvis Ridge to settle in nearby basement lows. The high-amplitude, onlap-fill reflections from these sediments sharply contrast with the low-amplitude, discontinuous reflections produced by the mudstones (Fig. 7). The mudstones and interbedded thin carbonates/fine-grained mud-silt turbidites dominated until mid-Coniacian time, when they are replaced by clays (Fig. 25).

The Albian-Early Cenomanian section contains black shales similar to other black shale deposits encountered throughout the South Atlantic (Bolli, Ryan, et al., 1978). These shales vary between 2 and $5 \mathrm{~cm}$ thick, contain very low amplitude ripples and faint, fine horizontal laminations, and are interbedded with red and green 
claystone turbidites. The organic matter in the shales is predominantly of marine origin.

The physical properties of the black shales do not differ significantly from the interbedded silts and clays. Therefore, they are not easily distinguished on the seismic profiles. However, low-amplitude, hummocky, and discontinuous reflections indicate that most of the early Cenomanian to mid-Coniacian sediments were deposited by turbidity currents controlled by the rough basin floor. Both the fine-grained lithologies and onlapping reflectors suggest that these turbidites represent the distal part of a prograding submarine fan complex. Locally divergent reflectors sloping away from basement highs in all directions also support continuing tectonic adjustment of basement at this time.

The sediment source for the black shales was probably the African continental margin. First, reflectors tend to slope and onlap to the west, suggesting an eastern source. Second, contemporaneous Walvis Ridge sediments are marly chalks, limestones, and calcareous muds, not red-green clays and black shales (Bolli, Ryan, et al., 1978).

Site 530 contains a hiatus from $90-86$ m.y. ago which is not apparent on the seismic profiles. This hiatus may be related to the early Late Cretaceous break-up between equatorial Africa and South America which produced open-marine circulation (Reyment and Tait, 1972) and, perhaps, stronger, more erosive bottom currents in the South Atlantic.

In the Coniacian-Santonian, clays and black shales began to be replaced by thin-bedded mud, silt, and marl turbidites interbedded with pelagic and hemipelagic sediments (Fig. 25). By 84 m.y. ago, black shales had disappeared completely, carbonate deposition was reduced, and the clastic turbidites had become thicker and coarser. Westward-dipping, higher-amplitude reflectors, together with an increase in sediment grain-size in the cores, mark the advancement of a westward-prograding submarine fan complex. The middle-fan lobe turbidites are now associated with moderate-amplitude, hummocky, and discontinuous seismic reflections. Divergent reflectors indicate that basement lows continued to subside relative to highs up until the end of the Conacian-Santonian, about $15 \mathrm{~m} . \mathrm{y}$. after basement formation.

The first sand-sized sediments reached the southeastern Angola Basin during the Coniacian-Santonian. Sandsilt-clay graded turbidite sequences, interpreted as upperfan lobe deposits, generally increased in frequency, thickness, and overall grain-size during the Campanian (Hay, Sibuet, et al., 1981). As the submarine fan continued to advance, fan valleys cut through the upper-fan lobe turbidites and are visible on both north-south and east-west seismic profiles (Figs. 7 and 10). Coarse-grained turbidites bypassed large areas of the fan through these valleys, and this controlled deposition resulted in a Campanian unconformity which is visible on seismic profiles over much of the study area though not identified at Site 530 (Fig. 25).

By the Campanian ( 83 m.y. ago), sandy turbidites consisting mostly of shallow-water debris blanketed the area. These turbidites probably cause the onlapping, channel-fill seismic facies occupying the fan valleys and overlying the Campanian unconformity on seismic profiles (Fig. 10). Greenish-black, volcanogenic and siliciclastic sands began to occur along with the lighter-colored siliciclastic sands, and the thickness and grain-size of the sandy turbidites increased. By $80 \mathrm{~m}$.y. ago, the dominant lithology was siliciclastic sands occurring as thin $(5-10 \mathrm{~cm})$ to thick $(1-3 \mathrm{~m})$, graded turbidites.

By the mid-Campanian, shallow-water carbonate debris gradually replaced siliciclastic sands as the dominant sand-sized material in the vicinity of Site 530. Sediments began to fine upward, and the lithology shifted from sandstone to green mudstone/marlstone with varying proportions of silt, clay, and carbonate. Corresponding reflections across the Unit 1/Unit 2 boundary show a slight decrease in reflector amplitude and an increase in continuity. By the Maestrichtian, noncalcareous coarse clastics had all but disappeared.

The entire late Albian to mid-Campanian depositional sequence correlates with seismic Unit 1 (Fig. 25). This is the first major cycle of sedimentation in the southeastern Angola Basin. Unit 1 represents a complete progradational submarine fan sequence from basinal and lower-fan deposits, through middle-fan lobe and channel sediments, to thick upper-fan sandstones. Near the top of the unit, a thinning and fining upward sequence records the transition from siliciclastic sediments to carbonates. Associated Unit 1 reflections progress from low-amplitude horizons which onlap basement topography in all directions, through moderate-amplitude, discontinuous, hummocky reflections dissected by a cutand-fill channeling facies, to slightly more continuous but lower-amplitude hummocky reflections.

Based on the seismic reflection profiles, the predominant sediment source for Unit 1 was the African continental margin (Fig. 11). Turbidity currents probably transported sediments from the margin down submarine canyons located to the east of the site survey area. The Walvis Ridge was not a major source of basin sediment at this time. However, the reflection profiles indicate major current activity at the base of the ridge. Unit 1 reflectors either prograde toward the ridge or onlap its base (Figs. 7 and 8), implying continuous reworking and filling around the ridge during the Late Cretaceous.

The progressive shift from siliciclastic to carbonate sands at the top of Unit 1 implies either a change in the location of the source area or a mixture of lithologies supplied from the margin. The fact that two coarse-clastic sediment types are commonly observed in interlaminated mixtures at Site $\mathbf{5 3 0}$ supports the latter mode of deposition, which may have been the result of dwindling supplies of continentally derived siliciclastic debris temporarily augmented by volcanogenic sands from a local volcanic source (perhaps the Walvis Ridge). As the volume of terrigenous sediments dwindled, carbonate debris became a more important component of the basin's sediments.

Seismic Unit 2 (late Campanian to late Eocene). The Campanian marks a major change in the provenance of Angola Basin sediments. The detrital bioclastic limestones which succeeded the siliciclastic sediments of 
Unit 1 include reefal debris. No reef-building is known to have occurred in the eastern South Atlantic after the late Aptian (DSDP Site $\mathbf{3 6 3}$ on the Walvis Ridge bottomed in late Aptian reefal limestones; Bolli, Ryan, et al., 1978), so erosion of older limestone deposits is suggested. Well-cemented clastic limestone turbidites vary in thickness up to $60 \mathrm{~cm}$, becoming thinner and finer upward in the Maestrichtian. Most of these bioclastic limestones are partly silicified and interbedded with greenish mudstone or highly bioturbated marlstone. This interbedding of high-velocity, silicified limestones and lowervelocity mudstones and marlstones produces the highamplitude reflections characteristic of Unit 2 (Fig. 13). In the lower half of the unit, hummocky reflections and channels (Fig. 10) also suggest continuing development of upper-fan lobes in a proximal fan environment.

By the end of the Maestrichtian, heightened planktonic activity increased the overall carbonate content of Angola Basin sediments at the expense of bioclastic limestone debris. Interbeds of nannofossil chalk became common in the Paleocene, with only an occasional bed of clastic limestone (Fig. 25). In the late Paleocene, there was a decrease in foraminifer-nannofossil chalk deposition and an associated increase in the amount of mud supplied to the basin. Throughout the early Eocene, only minor amounts of chalk and shallow-water limestone debris were interbedded with mudstone and marlstone turbidites. These Paleocene through Eocene sediments produce the more continuous, parallel, and even reflections at the top of Unit 2. Reflectors gently drape underlying topography, suggesting the presence of more slowly deposited pelagic or hemipelagic sediments. However, occasional interbedded limestone/chalk beds continue to produce high-amplitude reflections throughout Unit 2. At the base of the Walvis Ridge, sediments continue to be reworked. Unit 2 reflectors there appear to be channels filled by a complex onlap facies (Fig. 8).

The boundary between Units 2 and 3 is a high-amplitude unconformity (Figs. 13 and 14). Once believed to correlate with the Cretaceous horizon "AII"' in the Cape Basin (Emery et al., 1975; Bolli, Ryan, et al., 1978), this surface appears instead to be the result of a combination of geologic events spanning middle Eocene to late Oligocene time. In the late Eocene (anomaly 13 time), a tectonic readjustment in relative plate motion occurred between Africa and South America (Sibuet and Mascle, 1978) which initiated a series of volcanic events recorded in the continental stratigraphy of southern Africa (Moore, 1976). Also at about this time, deep-water circulation became more vigorous in response to cooling of surface waters around Antarctica (van Andel et al., 1977). The global onset of glacial conditions in the early Tertiary may have caused a sudden drop in sea level in the early Oligocene (Vail et al., 1977). Associated strong, deep currents probably caused a sudden rise of the CCD in the southern Angola Basin. The combined result of these events was a condensed stratigraphic section beginning in the middle Eocene, and an almost complete absence of carbonate sediments from 37 to $10 \mathrm{~m}$.y. ago at Site 530 (Fig. 25).
Seismic Unit 3 (late Oligocene to late Miocene). Sediment-starved conditions in the Angola Basin from the late Oligocene through the late Miocene were the result of an almost complete lack of terrigenous sediments combined with a shallow CCD (Hay, Sibuet et al., 1981). Occasionally, foram-nanno oozes were flushed from the nearby Walvis Ridge and buried before they could be completely dissolved, but the majority of sediments consisted of pelagic clays and an occasional silty turbidite. With the exception of the few, rare beds of foramnanno ooze, these sediments are essentially carbonatefree (Fig. 25). The almost reflection-free seismic response of Unit 3 is easily correlated with the silt/clay deposits, and the low interval velocity derived for this unit (1.65 km/s; Musgrove, 1982) also supports the existence of homogeneous, noncarbonate muds.

Several middle Miocene volcanic ash layers were encountered at Site 530 (Fig. 25). The ash layers may be a result of subaerial volcanic activity on a segment of the Walvis Ridge farther to the west. A minor seismic unconformity in Unit 3 (Fig. 7) could also be related to this volcanic activity, but it is not identified by a hiatus at Site 530 .

In the early late Miocene (10 m.y. ago), slowly deposited, noncalcareous, thin-bedded mud turbidites were replaced by calcareous biogenic sediments. This major change constitutes the Unit 3/Unit 4 boundary (Fig. 25). The very low-amplitude reflections at the top of Unit 3 were truncated and, in several locations along the base of the Walvis Ridge, deeply incised by erosion. The unconformity coincides with the establishment of the Benguela Current and an associated upwelling system (Siesser, 1980). As planktonic activity increased, a rapid deepening of the CCD occurred. Even though turbidity currents supplied some fine-grained clastics, most of the late Miocene sediment is pelagic nannofossil debris (Fig. 25).

Seismic Unit 4 (late Miocene to Recent). The late Miocene to Recent sediments of Unit 4 record a shift in provenance from the African continental margin to the Walvis Ridge. In the early late Miocene, the northwardflowing Benguela Current began to flush sediments from the ridge into the basin. Debris flows and turbidity currents must have funneled down canyons in the escarpment. Thick beds (up to $32 \mathrm{~m}$ ) of diatom-nanno marls containing large clasts (up to $60 \mathrm{~cm}$ long) of various lithologies (including basaltic pebbles), accompanied by clay- or carbonate-rich turbidites and interbedded with foram-nanno marls, record this activity at Site 530 (Fig. 25). The corresponding seismic stratigraphy of Unit 4 is dominated by moderate-amplitude, discontinuous, hummocky to lenticular reflections. The Unit 4 isopach map (Fig. 23) and the basinward trend of reflections from chaotic to hummocky to subparallel confirm that the Walvis Ridge was the source of the gravity-flow deposits. Small, onlapping mounds at the base of the unit (Fig. 20) suggest that the debris flows moved basinward at least $36 \mathrm{~km}$ from the foot of the ridge.

Near the end of the Pliocene, the CCD again rose sharply. This rise may correlate with the lowest seismic 
unconformity within Unit 4 (Fig. 19). The high-standing CCD resulted in low carbonate contents and was also accompanied by maximum upwelling conditions off the coast of southwest Africa. Diatom-rich ( $>40 \%$ ) pelagic sediments occur in the southern Angola Basin during the early Pleistocene (Fig. 25). This clayey diatom ooze was interbedded with thick $(20-100 \mathrm{~cm})$ clay-diatom turbidites and debris-flow deposits. However the transition to siliceous sediments in the Plio-Pleistocene cannot be detected on the seismic profiles.

The CCD gradually deepened through the mid-Pleistocene and Holocene to its present $4.75 \mathrm{~km}$ depth (van Andel et al., 1977). Continued high levels of biogenic activity resulted in mixed deposition of nannofossils, diatoms, and clay (in roughly that order of abundance). Debris flows continued to deposit diatom-clay turbidites up to about $1 \mathrm{~m}$ thick at Site 530 (Fig. 25).

Since the late Miocene, the depositional regime of the southeastern Angola Basin has been dominated by the development of submarine fans, particularly along the base of the Walvis Ridge. Ridge-derived sediments are also bypassing the foot of the escarpment to accumulate in the deep basin. An excellent example of this occurs along AM-33 (Fig. 22), where an 8-km wide valley occurs next to a $5-\mathrm{km}$ wide mound of Unit 4 sediments (Fig. 23). The seismic data also suggest that currents presently operative are causing the fans to prograde westward as well as basinward (Figs. 21 and 22).

\section{CONCLUSIONS}

Multichannel seismic reflection data were used to study the geologic evolution of the southern Angola Basin. Acoustic basement and four distinct seismic stratigraphic units (Fig. 26) could be identified and mapped.

Structural characteristics of the basement resemble characteristics described for crust formed at slow-spreading ridges today. The seismic profiles show acoustic basement consistently sloping away from the base of the Walvis Ridge, suggesting that the eastern ridge is composed of a material lighter than basaltic oceanic crust. This may support a hypothesis put forward by van der Linden (1980) that the core of the eastern portion of the ridge is a foundered block of continental crust.

When integrated with the lithologic column from DSDP Site 530, the seismic stratigraphic units correlate with four main depositional sequences (Fig. 25):

1) Late Albian-early Cenomanian to late Campanian. Basinal fine-grained mud turbidites from the African continental shelf were deposited over rough oceanfloor topography. Black shales were interbedded with the turbidites. In the late Coniacian, a siliciclastic submarine fan prograded across the basin. Volcanic activity in the Santonian temporarily augmented dwindling sediment supplies and added volcanogenic sands to the submarine fan complex.

2) Late Campanian to late Eocene. As continental clastics disappeared, carbonates eroded from the Walvis Ridge/continental margin resulted in the progradation of a detrital carbonate fan during the Campanian and Maestrichtian. Beginning in the Paleocene, sedimenta-

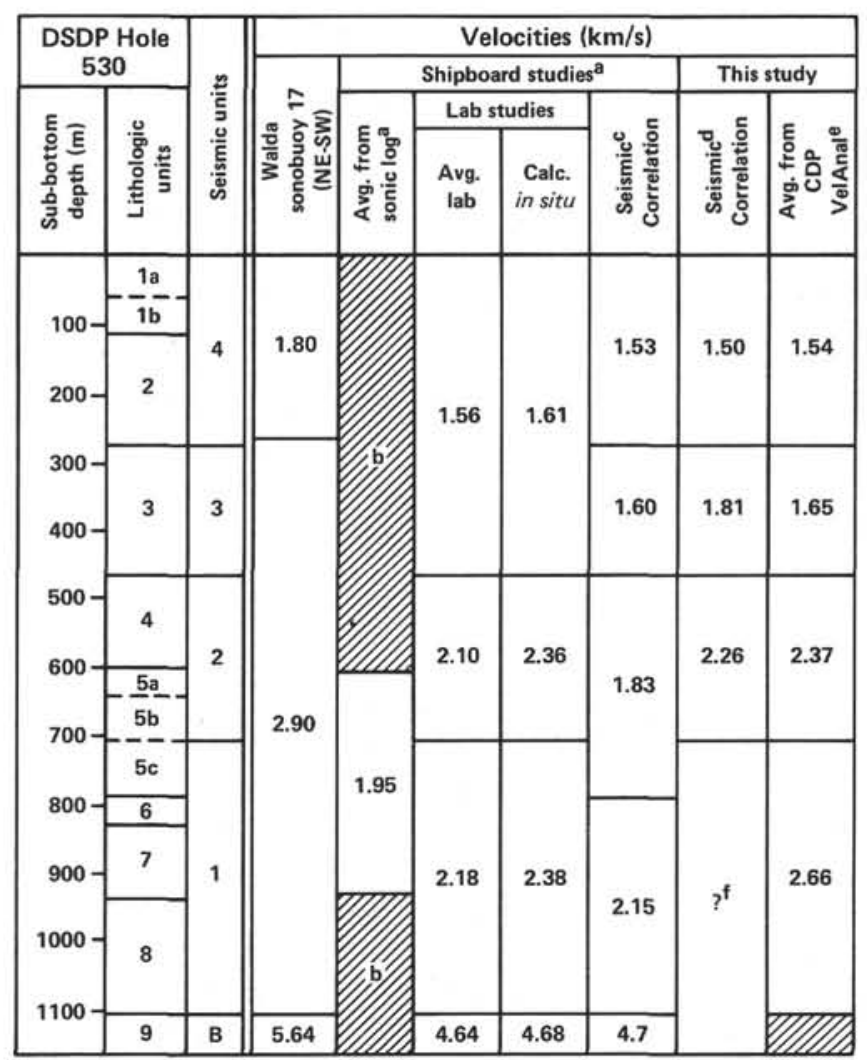

\footnotetext{
a DSDP Site 530 shipboard measurements and calculations.

b Borehole disturbed.

c From Preliminary Results of DSDP Leg 75.

d Based on seismic units traced throughout UTIG grid area correlated with single-channel Glomar Challenger profiles across Site 530.

e Velocities derived from analyses on UTIG CDP seismic data

used in this study for time-to-depth conversions.

f Top of acoustic basement unclear on seismic profile at Site 530 .
}

Figure 26. Site 530 lithologic units (Hay, et al., 1982) and southeastern Angola Basin seismic units (this investigation), each shown with their measured interval velocities. A hachured area indicates no velocity data for that interval.

tion rapidly decreased as the supply of detrital bioclastic carbonates disappeared. The early Tertiary sediments are thin and finer-grained.

3) Late Eocene to late Miocene. A series of events spanning late Eocene through mid-Oligocene time produced sediment-starved conditions in the Angola Basin. Because of a high-standing CCD and low terrigenous input, only a few Oligocene to late Miocene mud turbidites were deposited. Erosion of the continental shelf and slope during a mid-Miocene low-stand in sea level may have generated the majority of these sediments. This was the quietest period in the geologic history of the southeastern Angola Basin.

4) Late Miocene to Holocene. Sediment-starved conditions were alleviated in the middle-late Miocene when the modern Benguela Current system was established. From that time until the Present, the major sediment source has been the Walvis Ridge. Northward-flowing currents now flush ridge sediments into the basin, and upwelling conditions promote planktonic productivity and associated pelagic sedimentation. 


\section{ACKNOWLEDGMENTS}

The successful completion of the Angola Basin site survey work was the result of the efforts of many, many people. J. D. Phillips, R. T. Buffler, and F. J. Shaub helped collect the data aboard the R/V Fred H. Moore. The crew of the Moore is to be commended for their efforts under often trying conditions. S. Lapin, B. MacIsaac, and J. Kunselman helped to process the seismic data, and D. Moon operated the University of Texas TEMPUS computer system.

Assistance in data gathering and interpretation was provided by a large group, including E. Uchupi of Woods Hole Oceanographic Institution, M. Giarratano of Lamont-Doherty Geological Observatory, B. Long of Scripps Institution of Oceanography, and M. Backus of the University of Texas at Austin.

D. Angstadt, R. Rhair, T. Davies, and F. Taylor reviewed the manuscript and made many helpful suggestions.

This research was supported in large part by JOI-3, 26-39-54XX, "Surveys of the South Atlantic IPOD Drilling Sites" awarded to the University of Texas at Austin by Joint Oceanographic Institutions, Inc. (University of Texas Institute for Geophysics Contribution No. 538.)

\section{REFERENCES}

Allmendinger, R. W., and Riis, F., 1979, The Galapagos Rift at $86^{\circ} \mathrm{W}$, 1., Regional morphological and structural analysis. J. Geophys. Res., 84:5379-5389.

Ballard, R. D., Holcombe, R. T., and van Andel, Tj. H., 1979. The Galapagos Rift at $86^{\circ} \mathrm{W}$. 3. Sheet flows, collapse pits, and lava lakes of the rift valley. J. Geophys. Res., 84:5407-5422.

Ballard, R. D., and van Andel, Tj. H., 1977. Morphology and tectonics of the inner rift valley at lat. $36^{\circ} 51^{\prime} \mathrm{N}$ on the Mid-Atlantic Ridge. Geol. Soc. Am. Bull., 88:507-530.

Bolli, H. M., Ryan, W. B. F. et al., 1978. Init. Repts. DSDP, 40: Washington (U.S. Govt. Printing Office).

Detrick, R. S., and A. B. Watts, 1979. An analysis of isostasy in the world's oceans. 3. Aseismic ridges. J. Geophys. Res., 84:3637-3653.

Dingle, R. V., and Simpson, E. S. W., 1976. The Walvis Ridge: A review. In Drake, C. L. (Ed.), Geodynamics: Progress and Prospects: Washington (Am. Geophys. Union), pp. 160-176.

Emery, K. O., Uchupi, E., Bowin, C. O., Phillips, J., and Simpson, E. S. W., 1975. Continental margin of western Africa: Cape St. Francis (South Africa) to Walvis Ridge (South-West Africa). AAPG Bull., 59:3-59.

Francheteau, J., and LePichon, X., 1972. Marginal fracture zones as structural framework of continental margins in South Atlantic Ocean. AAPG Bull., 56:991-1007.

Goslin, J., and Sibuet, J.-C., 1975. Geophysical study of the easternmost Walvis Ridge, South Atlantic: Deep structure. Geol. Soc. Am. Bull., 86:1713-1724.

Hay, W. W., Sibuet, J.-C., and Shipboard Party, 1982. Sedimentation and accumulation of organic carbon in the Angola Basin and on the Walvis Ridge: Preliminary results of DSDP Leg 75. Geol. Soc. Am. Bull., 93:1038-1058.

1981. Leg 75 Walvis Ridge. JOIDES J., 7(1):17-29.

Kumar, N., 1979. Origin of "paired" aseismic rises: Ceara and Sierra Leone rises in the equatorial, and the Rio Grande Rise and Walvis Ridge in the South Atlantic. Mar. Geol., 30:175-191.

LePichon, X., and Hayes, D. E., 1971. Marginal offsets, fracture zones and the early opening of the South Atlantic. J. Geophys. Res., 76:6283-6293.

Moore, A. E., 1976. Controls of post-Gondwanaland alkaline volcanism southern Africa. Earth Planet. Sci. Lett., 31:291-296.

Musgrove, L. A., 1982. Geophysical investigation of the southern Angola Basin: SE Atlantic Ocean [M.S. dissert.]. Univ. of Texas at Austin.

Pitman, W. C., III, Larson, R. L., and Herron, E. M., 1974. The age of the ocean basins. Geol. Soc. Am. Map.

Rabinowitz, P. D., and LaBrecque, J., 1979. The Mesozoic South Atlantic Ocean and evolution of its continental margins. J. Geophys. Res., 84:5973-6002.

Reineck, H. E., and Singh, I. B., 1973. Depositional Sedimentary Environments: New York (Springer-Verlag).

Reyment, R. A., and Tait, E. A., 1972. Biostratigraphical dating of the early history of the South Atlantic Ocean. Phil. Trans. Roy. Soc. London, Ser. B., 264:551-95.

Sangree, J. B., and Widmier, J. M., 1977. Seismic stratigraphy and global changes of sea level, Part 9. Seismic interpretation of clastic depositional facies. In Payton, C. E. (Ed.), Seismic Stratigraphy-Application to Hydrocarbon Exploration. AAPG Mem., 26: 165-184.

Sibuet, J.-C., and Mascle, J., 1978. Plate kinematic implications of Atlantic equatorial fracture zone trends. J. Geophys. Res., 83: 3401-3421.

Siesser, W. G., 1980. Late Miocene origin of the Benguela upswelling (sic) system of northern Namibia. Science, 208:283-285.

Sleep, N. W., and Rosendahl, B. R., 1979. Topography and tectonics of mid-ocean ridge axes. J. Geophys. Res., 84:6831-6840.

Vail, P. R., Mitchum, R. M., Jr., and Thompson, S., III, 1977. Seismic stratigraphy and global changes of sea level, part 3: Relative changes of sea level from coastal onlap. AAPG Mem., 26:63-81.

van Andel, Tj. H., and Ballard, R. D., 1979. The Galapagos Rift at $86^{\circ} \mathrm{W}, 2$., Volcanism, structure, and evolution of the rift valley: $J$. Geophys. Res., 84:5340-5406.

van Andel, Tj. H., Thiede, J., Sclater, J. G., and Hay, W. W., 1977. Depositional history of the South Atlantic Ocean during the last 125 million years. J. Geol., 85:651-698.

van der Linden, W. J. M., 1980. Walvis Ridge, A piece of Africa? Geology, 8:417-421.

Date of Initial Receipt: October 13, 1982 